\title{
Diversity of nitrogen-fixing rhizobacteria associated with sugarcane: a comprehensive study of plant-microbe interactions for growth enhancement in Saccharum spp.
}

Rajesh Kumar Singh ${ }^{1,2,3 \dagger}{ }^{\text {}}$ Pratiksha Singh ${ }^{1,2,3 \dagger}$, Hai-Bi Li ${ }^{1,2}$, Qi-Qi Song ${ }^{1,2}$, Dao-Jun Guo ${ }^{1,2,3}$, Manoj K. Solanki ${ }^{4}$, Krishan K. Verma ${ }^{1,3}$, Mukesh K. Malviya ${ }^{1,3}$, Xiu-Peng Song ${ }^{1,2}$, Prakash Lakshmanan ${ }^{1,3,5}$, Li-Tao Yang ${ }^{2,3}$ and Yang-Rui $\mathrm{Li}^{1,2^{*}}$

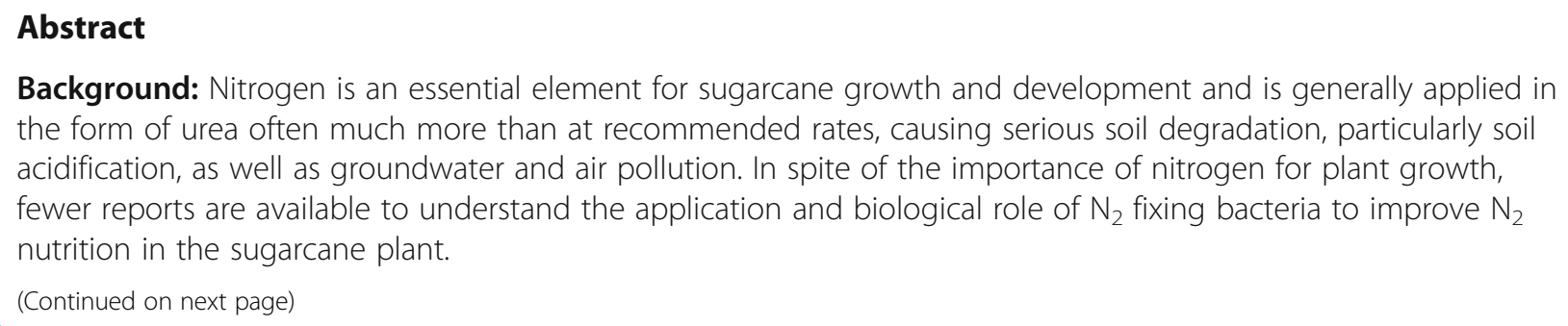

\footnotetext{
* Correspondence: liyr@gxaas.net; liyr@gxu.edu.cn

${ }^{+}$Rajesh Kumar Singh and Pratiksha Singh contributed equally to this work.

'Key Laboratory of Sugarcane Biotechnology and Genetic Improvement

(Guangxi), Ministry of Agriculture, Sugarcane Research Center, Chinese

Academy of Agricultural Sciences, Guangxi Key Laboratory of Sugarcane

Genetic Improvement, Sugarcane Research Institute, Guangxi Academy of

Agricultural Sciences, Nanning 530007, Guangxi, China

${ }^{2}$ College of Agriculture, State Key Laboratory of Conservation and Utilization

of Subtropical Agro-bio resources, Guangxi University, Nanning 530005,

China

Full list of author information is available at the end of the article
}

(c) The Author(s). 2020 Open Access This article is licensed under a Creative Commons Attribution 4.0 International License, which permits use, sharing, adaptation, distribution and reproduction in any medium or format, as long as you give appropriate credit to the original author(s) and the source, provide a link to the Creative Commons licence, and indicate if changes were made. The images or other third party material in this article are included in the article's Creative Commons. licence, unless indicated otherwise in a credit line to the material. If material is not included in the article's Creative Commons licence and your intended use is not permitted by statutory regulation or exceeds the permitted use, you will need to obtain permission directly from the copyright holder. To view a copy of this licence, visit http://creativecommons.org/licenses/by/4.0/ The Creative Commons Public Domain Dedication waiver (http://creativecommons.org/publicdomain/zero/1.0/) applies to the data made available in this article, unless otherwise stated in a credit line to the data. 
(Continued from previous page)

Results: In this study, a total of 350 different bacterial strains were isolated from rhizospheric soil samples of the sugarcane plants. Out of these, 22 isolates were selected based on plant growth promotion traits, biocontrol, and nitrogenase activity. The presence and activity of the nifH gene and the ability of nitrogen-fixation proved that all 22 selected strains have the ability to fix nitrogen. These strains were used to perform 165 rRNA and rpoB genes for their identification. The resulted amplicons were sequenced and phylogenetic analysis was constructed. Among the screened strains for nitrogen fixation, CY5 (Bacillus megaterium) and CA1 (Bacillus mycoides) were the most prominent. These two strains were examined for functional diversity using Biolog phenotyping, which confirmed the consumption of diverse carbon and nitrogen sources and tolerance to low pH and osmotic stress. The inoculated bacterial strains colonized the sugarcane rhizosphere successfully and were mostly located in root and leaf. The expression of the nifH gene in both sugarcane varieties (GT11 and GXB9) inoculated with CY5 and CA1 was confirmed. The gene expression studies showed enhanced expression of genes of various enzymes such as catalase, phenylalanine-ammonia-lyase, superoxide dismutase, chitinase and glucanase in bacterial-inoculated sugarcane plants.

Conclusion: The results showed that a substantial number of Bacillus isolates have N-fixation and biocontrol property against two sugarcane pathogens Sporisorium scitamineum and Ceratocystis paradoxa. The increased activity of genes controlling free radical metabolism may at least in part accounts for the increased tolerance to pathogens. Nitrogen-fixation was confirmed in sugarcane inoculated with B. megaterium and B. mycoides strains using $\mathrm{N}$-balance and ${ }^{15} \mathrm{~N}_{2}$ isotope dilution in different plant parts of sugarcane. This is the first report of Bacillus mycoides as a nitrogen-fixing rhizobacterium in sugarcane.

Keywords: Genetic diversity, GFP, Microbe-plant interactions, Nitrogen-fixing bacteria, PGPR, ${ }^{15} \mathrm{~N}_{2}$ isotope, qRT-PCR, Sugarcane

\section{Background}

Sugarcane (Saccharum officinarum L.) is the world's largest sugar crop and globally the second largest source of biofuel $[1,2]$. It is also an increasingly important source of raw materials for animal feed, paper production, and many biomass-based products [3]. China ranks the third-largest sugarcane growing country, producing about ten million tons of sugar annually [2]. Yet, it is now the largest sugar importer in the world due to increasing local consumption. Given this commercial reality, there is a strong impetus to increase sugarcane production area and crop productivity in China. Sugarcane is a fast-growing high-biomass crop and its nutrient and water requirements are relatively large. There is a huge variation for nitrogen $(\mathrm{N})$ fertilizer application for sugarcane production between countries, ranging from as little as $60 \mathrm{~kg} \mathrm{Nha}^{-1}$ in some regions of Brazil to as high as $755 \mathrm{~kg} \mathrm{Nha}^{-1}$ in some parts of China [4]. In China, the excessive application of $\mathrm{N}$ fertilizer in sugarcane crop, spurred by the low cost of fertilizer and as an insurance strategy to achieve high cane yield, is causing considerable soil degradation as well as air and groundwater pollution [5]. Further, the high use of $\mathrm{N}$ fertilizer adversely affects sugar quality and dramatically alters soil biota, which often results in a substantial decline in beneficial microflora associated with $\mathrm{N}$ mineralization and supply. Compounding these issues is the regulatory pressure felt across agriculture, including the sugarcane industry, to reduce greenhouse gas emission from agriculture to mitigate soil degradation and climate change [6].

The need for reducing chemical $\mathrm{N}$ fertilizer dependency prompted research on sustainable alternative nitrogen sources for crop production [7]. Soil microorganisms and plant microbial endophytes including rhizobacteria have been reported to promote plant growth, suppress pathogens and in some instances improve abiotic stress tolerance [8, 9]. More specifically, plant growth-promoting rhizobacteria (PGPR) with nitrogenfixing ability are reported to be a valuable source of nitrogen for sustainable crop production as well as to maintain soil fertility [3]. Several groups of soil and rootassociated nitrogen-fixing microorganisms such as $A z o-$ tobacter vinelandii [10], Azospirillum brasilense, Azospirillum zeae, and Pseudomonas stutzeri [11], Acetobacter diazotrophicus [12], Achromobacter insolitus [13], Bacillus megaterium [14], Bacillus rhizosphaerae [15], Burkholderia tropica [16], Burkholderia xenovorans [17], Burkholderia silvatlantica [18], and Burkholderia caballeronis [19], Bradyrhizobium. japonicum and B. elkanii, [20], Delftia tsuruhatensis [21], Enterobacter sacchari [22], Gluconacetobacter diazotrophicus [23], Gluconacetobacter diazotrophicus [24], Stenotrophomonas maltophilia [25], Pseudomonas koreensis, and P. entomophila [7] have been found to colonize different crops and stimulate plant growth either directly or indirectly. Their activity, however, is influenced by crop species, soil type and soil condition [26]. Therefore, it is important to 
isolate, identify, and culture PGPRs associated with sugarcane that functions optimally in different soil types and climatic conditions to promote crop growth and yield.

The nitrogen-fixing Bacillus species have the potential to use as a microbial bio-fertilizer and biocontrol in agriculture sectors [27]. Therefore, in this study, we focused on the bacteria belonging to nitrogen-fixing Bacillus species. Bacillus spp. occur in very different soil types and they can be cultured. They have a complex cell wall and, stress-resistant endospore they produce antibiotics and extracellular lytic enzymes, and tolerate adverse environmental conditions for extended periods [28, 29]. Several Bacillus species such as Bacillus tequilensis, $B$. megaterium, $B$. cereus [30, 31], B. amyloliquefaciens, $B$. aryabhattai, B. safensis, B. aerophilus, B. subtilis [31, 32], B. rhizosphaerae [15], B. pumilus [31], B. fluminensis [33] and $B$. indica [34] have been isolated from sugarcane. These micro-organisms promote plant growth directly via nitrogen fixation, phosphate solubilization and production of phytohormones, and indirectly through the production of antibiotics, hydrolytic enzymes and siderophores [3, 34-37].

Many Bacillus species fix $\mathrm{N}_{2}$ and the occurrence of $\mathrm{N}_{2}$ fixing bacteria in sugarcane was first reported by Dobereiner and Ruschel [38], which was confirmed by later studies $[23,39,40]$. Based on nitrogenase activity, Xie et al. [41] showed that Bacillus brevis, B. cereus, B. circulans, B. firmus, B. licheniformis, B. megaterium, B. pumilus, and B. subtilis associated with rice have the capacity to fix nitrogen. Recently, Paenibacillus odorifer, P. graminis, $P$. peoriae, and $P$. brasilensis have been described as nitrogen fixers in other plants [42-44], with the presence of nifH gene established in, $P$. graminis and $P$. odorifer [43, 45].

Microbial colonization is an important aspect of successful plant-microorganism interactions [46]. In many instances, artificially inoculated PGPRs failed to colonize target hosts grown in the soil. The reason for poor colonization by externally supplied PGPRs, especially when plants are grown in soil, is not known, and this currently limits the application of PGPRs in many commercial crops, including sugarcane [47]. Hence, the objectives of this study are (i) to isolate nitrogen-fixing microorganisms from the rhizosphere of Chinese sugarcane germplasm and characterize them for nitrogen fixation, plant growth promotion and biocontrol of sugarcane pathogens, and (ii) to understand how the host and the growing environment control the colonization process. Using several experimental tools and strategies relevant to rhizosphere and microbiome association studies, such as the expression of the nifH gene, ${ }^{15} \mathrm{~N}_{2}$ tracer studies, confocal microscopy, and $\mathrm{N}_{2}$ fixation-associated metabolic changes, this important plant-microbe interaction has been studied and the results are presented here.

\section{Results \\ Isolation and characterization of rhizosphere bacteria with PGP ability}

A total of 350 bacterial isolates were obtained from the sugarcane rhizosphere. Out of these, 102 isolates were selected with different PGP traits, and nitrogenase activity and were tested in vitro for antagonistic activity against sugarcane pathogens. Following this screening, 22 of them were selected for further studies (Fig. 1a-b).

All the isolated sugarcane rhizosphere bacteria were primarily screened to analyze their biocontrol property against the pathogens Sporisorium scitamineum and Ceratocystis paradoxa. A total of 18 such isolates with biocontrol property were selected. The data in Table 1 , indicated that about 40 (9) and 60\% (13) of the isolates were antagonistic to S. scitamineum and C. paradoxa respectively. All the selected isolates were screened for their capacity to solubilize phosphate using Pikovskaya's plates. The results showed that $82 \%$ (18) of tested isolates produced a halo zone, indicating their capacity to produce organic acids to solubilize the tri-calcium phosphate in the media. Among the 22 bacterial isolates tested, $45.5 \%$ (10) were able to produce an orange halo zone on the chrome azurol S agar medium indicating siderophores production. Further, about $60 \%$ (13) of the isolates produced ammonia and $18 \%$ (4) produced hydrogen cyanide ( $\mathrm{HCN})$ (Table 1).

Phosphate and siderophore activity of the bacterial isolates $3 \mathrm{~mm}$ or greater clear zone of inhibitions on suitable medium after $3-5$ days of incubation at $30 \pm 2{ }^{\circ} \mathrm{C}$.

Antifungal activity by dual culture plate measured as a zone of inhibition after 3-5 days of incubation at $26 \pm$ $2{ }^{\circ} \mathrm{C}$.

The ability to synthesize Indole-3-acetic acid (IAA) is an important feature of PGPR isolates. The data in Table 2, shows that the isolates had a very diverse capacity to synthesize IAA. These variations ranged from $11.42 \pm 0.49$ to $44.88 \pm 0.19 \mu \mathrm{g} \mathrm{mL}^{-1}$ in a medium without tryptophan but the addition of tryptophan resulted in $29.65 \pm 0.61$ to $316.84 \pm 2.5 \mu \mathrm{g} \mathrm{mL}^{-1}$. The isolates CoY8 and CY5 showed the lowest and highest IAA production, respectively in the absence of tryptophan. However, in the presence of tryptophan, the lowest and highest production of IAA was observed in isolates CA8 and AY8, respectively. The level of nitrogenase activities varied greatly amongst the twenty-two bacterial isolates tested. The nitrogen-fixing ability among the isolates ranged from $2.40 \pm 0.24$ to $26.59 \pm 2.0 \mathrm{n} \mathrm{moL} \mathrm{C}_{2} \mathrm{H}_{4} \mathrm{mg}$ protein $\mathrm{h}^{-1}$. Isolate AN11 showed the highest and CY10 recorded the lowest activity using an acetylene reduction assay. 1-aminocyclopropane-1-carboxylate (ACC) 


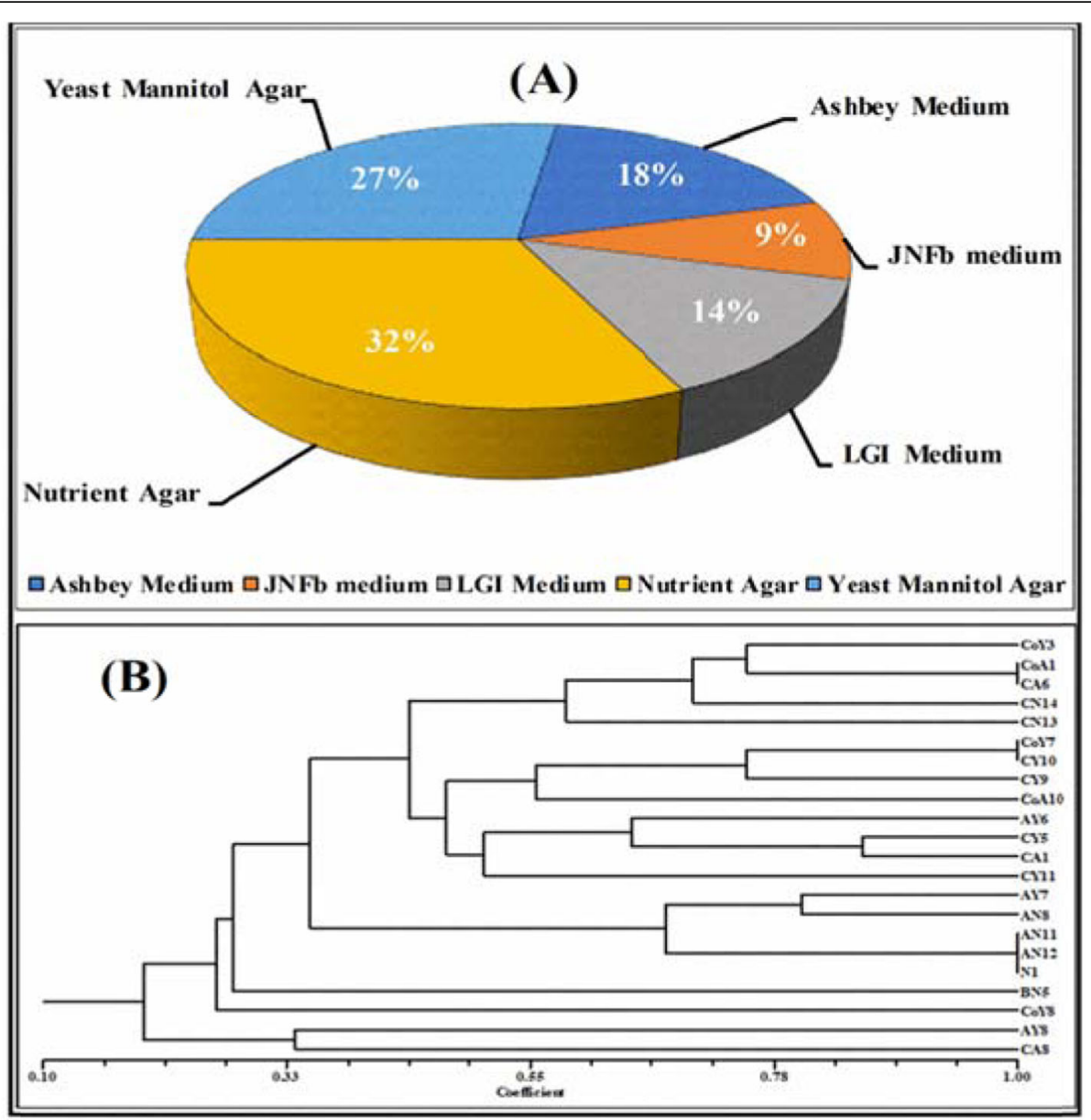

Fig. 1 a Assortment of nitrogen-fixing micro-organisms from the rhizosphere of sugarcane plants in a different medium, $\mathbf{b}$ A dendrogram was constructed on the basis of functional characterization of different PGP traits for all selected isolates

deaminase activity was determined as the ability to use ACC as the sole $\mathrm{N}_{2}$ source. Of the 22 isolates, 10 (45.5\%) were able to grow normally on the DF medium supplemented with $3 \mathrm{~m} \mathrm{moL} \mathrm{L}{ }^{-1}$ of ACC after $36-48 \mathrm{~h}$ incubation at $30 \pm 2{ }^{\circ} \mathrm{C}$. Subsequently, the color of bacteria appeared dark in the DF medium with ACC. On the basis of the above results, 10 of the isolates were selected for further quantitative tests and found varying levels of ACC deaminase amongst them (Table 2). The highest activity was found in the CY5 $(75.63 \pm 3.35)$ with CA8 registering the lowest level $(16.47 \pm 0.42)$, and all these selected strains showed the amplification approximately $755 \mathrm{bp}$ of acdS gene (Additional file 1: Fig. S1).

\section{Molecular characterization of bacterial isolates}

In the present study, the $16 \mathrm{~S}$ and $r p o B$ rRNA gene amplification was done. The amplified fragment was used for 16S rRNA gene partial sequencing and basic local alignment search tool (BLAST) analysis for judging the sequence similarity with the national center for biotechnology information (NCBI) GenBank database.
The results displayed that all the isolates belonged to the Bacillus genus (Table 3). Based on the similarity value $\geq 97 \%$ score, we separated the Bacillus into 13 different species including 3 belongs to $B$. species, 1 to $B$. licheniformis, 3 to B. pumilus, 2 to B. safensis, 1 to Firmicutes bacterium, 1 to $B$. luciferensis, 1 to Paenibacillus lautus, 2 to $B$. cereus, 2 to $B$. subtilis, 3 to $B$. thuringiensis, 1 to B. megaterium, 1 to $B$. aryabhattai, and 1 to $B$. mycoides. In addition, we found that some isolates belonged to the same species, as determined by the $16 \mathrm{~S}$ rRNA gene sequences. Another primer set of rpoB gene was also used for the amplification of partial sequences of the genes. As shown in Table 3, the rpoB gene sequence homology analysis failed to discriminate against the isolates CoA10, AY6, and CY11.

\section{Phylogenetic structure of $16 \mathrm{~S}$ rRNA and rpoB genes}

The individual analysis for a phylogenetic tree for the evolutionary relationship was done. The $16 \mathrm{~S}$ rRNA and $r p o B$ gene partial sequences of the isolated strains were compared with the reference strains of the NCBI 
Table 1 In vitro characterization of rhizospheric bacteria on the basis of plant growth promotion attributes exhibited by selected isolates

\begin{tabular}{|c|c|c|c|c|c|c|c|}
\hline \multirow{2}{*}{$\begin{array}{l}\text { Culture } \\
\text { Code }\end{array}$} & \multirow[t]{2}{*}{ Phosphate } & \multirow[t]{2}{*}{ Siderophore } & \multirow[t]{2}{*}{ Ammonia } & \multirow[t]{2}{*}{$\mathrm{HCN}$} & \multirow{2}{*}{$\begin{array}{l}\text { ACC } \\
\text { deaminase }\end{array}$} & \multicolumn{2}{|l|}{ Antifungal activity } \\
\hline & & & & & & Sporisorium scitamineum & Ceratocystis paradoxa \\
\hline CoY3 & + & - & +++ & - & - & + & + \\
\hline CoY7 & + & - & ++ & - & + & ++ & - \\
\hline CoY8 & - & - & ++ & + & - & - & ++ \\
\hline COA1 & + & - & ++ & - & - & - & + \\
\hline CoA10 & +++ & - & - & - & - & ++ & - \\
\hline AY6 & ++ & +++ & - & ++ & + & ++ & - \\
\hline AY7 & +++ & ++ & - & - & + & - & +++ \\
\hline AY8 & - & ++ & ++ & - & - & - & - \\
\hline AN8 & +++ & +++ & - & ++ & + & - & + \\
\hline AN11 & ++ & +++ & - & - & - & - & +++ \\
\hline AN12 & ++ & +++ & - & - & - & - & ++ \\
\hline BN5 & ++ & - & - & - & - & - & - \\
\hline CY5 & ++ & ++ & ++ & - & + & ++ & ++ \\
\hline CY9 & ++ & - & ++ & - & - & ++ & - \\
\hline CY10 & ++ & - & ++ & - & + & ++ & - \\
\hline CY11 & - & - & ++ & - & + & + & + \\
\hline CA1 & ++ & +++ & ++ & +++ & + & ++ & + \\
\hline CA6 & ++ & - & +++ & - & - & - & + \\
\hline CA8 & - & +++ & - & - & + & - & - \\
\hline CN13 & ++ & - & ++ & - & - & - & - \\
\hline CN14 & ++ & - & ++ & - & + & - & + \\
\hline N1 & ++ & ++ & - & - & - & - & ++ \\
\hline
\end{tabular}

$(+)=$ low activity; $(++)=$ moderate activity; $(+++)=$ strong activity; $(-)=$ no activity

GenBank public database. In $16 \mathrm{~S}$ rRNA genes two major and two minor groups were formed based on the NJ method with 1000 bootstrap sampling (Fig. 2a). Pseudomonas putida was used as the reference to separate $\mathrm{Ba}$ cillus strains. However, in the case of the $r p o B$ gene three major and two minor groups were formed (Fig. 2b).

\section{Amplification of the nifH gene}

To investigate the nifH gene for all the selected isolates, the genomic DNA extracted and used to detect the PCR products with an accurate band size of about $360 \mathrm{bp}$. Results showed that six strains were positive for nifH gene amplification (Additional file 2: Fig. S2). The positive isolates were used to establish nifH clone libraries and ten clones were selected from each isolate for sequencing. All the sequenced clones were found to be similar to the nifH gene by the BlastN search program from the NCBI GenBank database. These isolates were similar to B. cereus (AY8), B. subtilis (AN8), B. cereus (BN5), B. megaterium (CY5), B. pumilus (CY10), and B. pumilus (CA6). The nifH sequences identified were submitted to
NCBI GenBank and their accession numbers are from KY652155 to KY652160.

\section{Characterization of genomic fingerprinting}

A genomic fingerprint was examined by A1R-based repetitive extragenic palindromic (BOX) and enterobacterial repetitive intergenic consensus (ERIC) PCR using the purified DNA of selected isolates from the sugarcane rhizosphere. Many polymorphic bands were observed approximately ranging between $100 \mathrm{bp}$ and about $5 \mathrm{~kb}$. The genomic DNA fingerprints generated from all the isolates were clearly distinguished from each other. High-quality fingerprint profiles were visualized on agarose gels with each primer set (Fig. 3). The BOX and ERIC-PCR fingerprints results were very complicated with several polymorphic bands with different intensity. A total of 174 bands ranging from $50 \mathrm{bp}$ to $5 \mathrm{~kb}$ were generated from all the 22 selected Bacillus strains through BOX PCR. The isolate B9 and B14 showed the maximum 11 bands, after this B1, B4, and B7 showed a similar number of bands (10), while a minimum of 4 bands was detected in B2, and B4 isolates (Fig. 3a; 
Table $\mathbf{2}$ In vitro screening of the bacterial isolates for IAA production, ARA, and ACC deaminase activity

\begin{tabular}{|c|c|c|c|c|}
\hline \multirow{2}{*}{$\begin{array}{l}\text { Culture } \\
\text { Code }\end{array}$} & \multicolumn{2}{|l|}{ IAA $\left(\mu \mathrm{g} \mathrm{mL}^{-1}\right)$} & \multirow{2}{*}{$\begin{array}{l}\text { ARA } \\
\text { (n moL } \mathrm{C}_{2} \mathrm{H}_{4} \\
\mathrm{mg}^{-1} \text { protein } \\
\mathrm{h}^{-1} \text { ) }\end{array}$} & \multirow{2}{*}{$\begin{array}{l}\text { ACC } \\
\text { (nmol a- } \\
\text { ketobutyrate } \\
\mathrm{mg}^{-1} \mathrm{~h}^{-1} \text { ) }\end{array}$} \\
\hline & A-Tryptophan & P-Tryptophan & & \\
\hline CoY3 & $11.61 \pm 0.49^{1}$ & $36.35 \pm 0.10^{\mathrm{nm}}$ & $10.04 \pm 1.65^{h}$ & - \\
\hline CoY7 & $15.70 \pm 0.34^{h}$ & $44.82 \pm 0.61^{\mathrm{k}}$ & $16.65 \pm 1.25^{\mathrm{fg}}$ & $34.72 \pm 5.33^{d}$ \\
\hline CoY8 & $11.42 \pm 0.49^{\prime}$ & $49.26 \pm 0.69^{j}$ & $17.65 \pm 0.27^{\mathrm{ef}}$ & - \\
\hline COA1 & $17.12 \pm 0.33^{\mathrm{fg}}$ & $42.14 \pm 0.21^{1}$ & $5.53 \pm 0.56^{i}$ & - \\
\hline CoA10 & $12.56 \pm 0.25^{\mathrm{kl}}$ & $51.84 \pm 0.10^{i j}$ & $16.74 \pm 0.18^{f g}$ & - \\
\hline AY6 & $14.10 \pm 0.34^{i j}$ & $49.20 \pm 0.34^{j}$ & $21.38 \pm 2.42^{\mathrm{cd}}$ & $19.60 \pm 0.89^{e}$ \\
\hline AY7 & $26.25 \pm 0.51^{d}$ & $53.84 \pm 0.27^{i}$ & $21.59 \pm 3.65^{c d}$ & $39.80 \pm 1.10^{c}$ \\
\hline AY8 & $17.27 \pm 0.20^{f g}$ & $316.84 \pm 2.5^{b}$ & $25.89 \pm 2.08^{\mathrm{ab}}$ & - \\
\hline AN8 & $19.13 \pm 0.51^{e}$ & $290.57 \pm 2.62^{c}$ & $24.73 \pm 0.61^{\mathrm{ab}}$ & $17.42 \pm 0.55^{\mathrm{e}}$ \\
\hline AN11 & $39.92 \pm 2.95^{b}$ & $104.62 \pm 0.51^{h}$ & $26.59 \pm 2.05^{a}$ & - \\
\hline AN12 & $17.37 \pm 0.61^{f}$ & $112.27 \pm 1.28^{9}$ & $19.70 \pm 0.67^{\text {de }}$ & - \\
\hline BN5 & $15.41 \pm 0.11^{\mathrm{h}}$ & $271.06 \pm 2.45^{d}$ & $23.62 \pm 1.15^{b c}$ & - \\
\hline CY5 & $44.88 \pm 0.19^{a}$ & $35.01 \pm 0.30^{\mathrm{mn}}$ & $23.87 \pm 2.55^{b c}$ & $75.63 \pm 3.35^{\mathrm{a}}$ \\
\hline CY9 & $14.03 \pm 0.30^{i j}$ & $49.33 \pm 0.63^{j}$ & $25.87 \pm 1.72^{\mathrm{ab}}$ & - \\
\hline CY10 & $14.98 \pm 0.26^{h i}$ & $33.84 \pm 0.11^{n}$ & $2.40 \pm 0.24^{j}$ & $32.92 \pm 4.23^{d}$ \\
\hline CY11 & $43.77 \pm 0.23^{\mathrm{a}}$ & $175.73 \pm 0.91^{\mathrm{e}}$ & $16.12 \pm 0.94^{\mathrm{fg}}$ & $41.57 \pm 3.91^{c}$ \\
\hline CA1 & $16.14 \pm 0.10^{g h}$ & $130.96 \pm 1.81^{f}$ & $15.94 \pm 2.11^{\mathrm{fg}}$ & $49.61 \pm 1.15^{b}$ \\
\hline CA6 & $13.28 \pm 0.25^{j k}$ & $37.10 \pm 0.41^{\mathrm{m}}$ & $14.23 \pm 1.07^{9}$ & - \\
\hline CA8 & $17.42 \pm 0.18^{f}$ & $29.65 \pm 0.61^{\circ}$ & $15.08 \pm 1.17^{\mathrm{fg}}$ & $16.47 \pm 0.42^{e}$ \\
\hline CN13 & $28.28 \pm 0.47^{c}$ & $36.12 \pm 1.93^{\mathrm{mn}}$ & $16.87 \pm 0.92^{\mathrm{fg}}$ & $21.05 \pm 1.04^{e}$ \\
\hline CN14 & $13.90 \pm 0.19^{i j}$ & $37.56 \pm 0.30^{\mathrm{m}}$ & $16.92 \pm 1.71^{\mathrm{fg}}$ & - \\
\hline N1 & $18.64 \pm 0.15^{e}$ & $339.07 \pm 5.56^{\mathrm{a}}$ & $17.69 \pm 0.76^{\text {ef }}$ & - \\
\hline SEM & 0.39 & 0.89 & 0.86 & 1.62 \\
\hline $\mathrm{CD}(P=0.05)$ & 1.12 & 2.55 & 2.44 & 4.87 \\
\hline CV (\%) & 3.40 & 1.50 & 8.30 & 7.60 \\
\hline
\end{tabular}

A-Tryptophan absence of tryptophan, P-Tryptophan presence of tryptophan.

Means followed by the same letter within a row are not significantly different $(p \leq 0.05)$ according to Duncan's Multiple Range Test (DMRT). SEM standard error of the difference between means, $C D$ critical difference, $C V$ coefficient of variation

Additional file 3: Fig. S3). For ERIC-PCR the faint bands were frequently observed and approximately $50 \mathrm{bp}$ to 5 $\mathrm{kb}$ of 146 bands were identified. The maximum number of bands was observed in three strains i.e., B1, B2, and B9 (10), whereas the minimum bands were found in B13 (3) (Fig. 3c; Additional file 3: Fig. S4).

BOX-PCR fingerprints showed more genotypic diversity for all selected Bacillus spp. as compared to ERIC fingerprints, and a dendrogram was created of fingerprint bands to generate their relatedness (Fig. 3). The data were examined by Jaccard similarity coefficients and the neighbor-joining method based on UPGMA. Two major clusters, one comprising two isolates and the other comprising twenty isolates were found in dendrogram created through BOX PCR fingerprints (Fig. 3b). These eighteen isolates were further divided into two sub-groups, one contained 6 isolates and the other had fourteen isolates. In the ERIC-PCR, all the twenty-two isolates showed two major clusters, containing one and twenty-one isolates, respectively. The twenty-one isolates were divided into two sub-groups, which contained 3 and 17 isolates, and all were grouped into different clusters (Fig. 3d).

\section{Biolog phenotypic profiling of CY5 and CA1}

The substrate utilization patterns for the selected strains (CY5 and CA1) were established for metabolic potential with numerous groupings such as carbon $(\mathrm{C})$, and nitrogen $(\mathrm{N})$ sources, tolerance of osmotic stress and metabolic activity over a wide range of $\mathrm{pH}(3.5-10)$. The physiological, biochemical, and chemical sensitivity of the isolates was performed by the Biolog system based on substrate use. The results showed that the strain CA1 utilized more carbon sources as compared to CY5 i.e. 
Table 3 Identification of selected bacterial strains isolated from sugarcane-based on $16 \mathrm{~S}$ rRNA and rpoB gene sequence

\begin{tabular}{|c|c|c|c|c|c|c|c|c|}
\hline \multirow[t]{2}{*}{ Isolates } & \multicolumn{2}{|c|}{ Identified by two genes: A (16S rRNA) and B (rpoB) } & \multicolumn{2}{|c|}{$\%$ identity $^{a}$} & \multicolumn{2}{|c|}{ No. of Nucleotides ${ }^{\mathbf{b}}$} & \multicolumn{2}{|c|}{ Accessions Number ${ }^{c}$} \\
\hline & A & B & A & B & A & B & A & B \\
\hline CoY3 & Bacillus spp. & Bacillus spp. & 98 & 97 & 1452 & 779 & KY652111 & KY652133 \\
\hline CoY7 & Bacillus licheniformis & Bacillus licheniformis & 98 & 96 & 1396 & 547 & KY652112 & KY652134 \\
\hline CoY8 & Bacillus pumilus & Bacillus pumilus & 99 & 99 & 1447 & 1166 & KY652113 & KY652135 \\
\hline COA1 & Bacillus safensis & Bacillus safensis & 99 & 99 & 1447 & 1178 & KY652114 & KY652136 \\
\hline CoA10 & Firmicutes bacterium & Bacillus cereus & 98 & 98 & 1490 & 1080 & KY652115 & KY652137 \\
\hline AY6 & Bacillus luciferensis & Bacillus amyloliquifensis & 98 & 96 & 1497 & 581 & KY652116 & KY652138 \\
\hline AY7 & Paenibacillus lautus & Paenibacillus lautus & 97 & 96 & 1389 & 352 & KY652117 & KY652139 \\
\hline AY8 & Bacillus cereus & Bacillus cereus & 99 & 99 & 1414 & 1104 & KY652118 & KY652140 \\
\hline AN8 & Bacillus subtilis & Bacillus subtilis & 99 & 99 & 1462 & 1149 & KY652119 & KY652141 \\
\hline AN11 & Bacillus thuringiensis & Bacillus thuringiensis & 98 & 96 & 1474 & 778 & KY652120 & KY652142 \\
\hline AN12 & Bacillus subtilis & Bacillus subtilis & 99 & 97 & 1458 & 1094 & KY652121 & KY652143 \\
\hline BN5 & Bacillus cereus & Bacillus cereus & 98 & 96 & 1392 & 840 & KY652122 & KY652144 \\
\hline CY5 & Bacillus megaterium & Bacillus megaterium & 98 & 97 & 1403 & 690 & KY652123 & KY652145 \\
\hline CY9 & Bacillus safensis & Bacillus safensis & 99 & 98 & 1354 & 1164 & KY652124 & KY652146 \\
\hline CY10 & Bacillus pumilus & Bacillus pumilus & 99 & 98 & 1375 & 1165 & KY652125 & KY652147 \\
\hline CY11 & Bacillus aryabhattai & Bacillus altitudinis & 99 & 98 & 1455 & 1139 & KY652126 & KY652148 \\
\hline CA1 & Bacillus mycoides & Bacillus mycoides & 98 & 96 & 1413 & 781 & KY652127 & KY652149 \\
\hline CA6 & Bacillus pumilus & Bacillus pumilus & 99 & 98 & 1459 & 1155 & KY652128 & KY652150 \\
\hline CA8 & Bacillus thuringiensis & Bacillus thuringiensis & 99 & 98 & 1461 & 1211 & KY652129 & KY652151 \\
\hline CN13 & Bacillus spp. & Bacillus spp. & 97 & 97 & 1457 & 800 & KY652130 & KY652152 \\
\hline CN14 & Bacillus spp. & Bacillus spp. & 98 & 98 & 1518 & 775 & KY652131 & KY652153 \\
\hline N1 & Bacillus thuringiensis & Bacillus thuringiensis & 98 & 96 & 1411 & 694 & KY652132 & KY652154 \\
\hline
\end{tabular}

${ }^{a}$ The percentage identity with the $16 \mathrm{~S}$ rDNA/ rpoB gene sequence of the closest phylogenetic relative

${ }^{\mathrm{b}}$ The number of $16 \mathrm{~S}$ rDNA/ rpoB gene nucleotides used for the alignment

${ }^{\mathrm{C}} \mathrm{NCBI}$ GenBank accession number of $16 \mathrm{~S}$ rDNA/ rpoB gene

sugars (74.07\%), carboxylic acids (66.67\%), hexose acids (88.89\%), and amino acids (100.00\%), and the highest chemical sensitivity (86.97\%) (Additional file 4: Table S1). Along with, reducing sugar, sodium chloride, amino acid, lactic acid, and hexose- $\mathrm{PO}_{4}$ were used. In both tested strains, $79(82.29 \%)$ of CA1 and $61(63.54 \%)$ of CY5 compounds were utilized (Fig. 4).

Different nitrogen sources support the growth of CY5 and CA1, indicating that these isolates metabolize compounds such as ammonia, nitrite, nitrate, urea, biuret, 1alanine, glycine, hydroxylamine methylamine, ethylamine, ethanolamine, adenine, cytosine, thymine, uracil, and uric acid, and they might tolerate nearly 95 different forms of nitrogen and some related chemicals even at high concentrations. The tolerance levels of isolates CY5 and CA1 to different concentrations of $\mathrm{NaCl}(1-10 \%)$, potassium chloride (3-6\%), sodium sulfate (2-5\%), ethylene glycol (5-20\%), sodium formate $(1-6 \%)$, urea $(2-7 \%)$, sodium lactate $(1-$ $12 \%)$, sodium phosphate $\mathrm{pH} 7(20-200 \mathrm{mM})$, sodium benzoate pH $5.2(20-200 \mathrm{mM})$, ammonium sulfate $\mathrm{pH} 8$ $(10-100 \mathrm{mM})$, sodium nitrate $(10-100 \mathrm{mM})$ and sodium nitrite $(10-100 \mathrm{mM})$ were high. In the case of metabolic activity, both isolates could grow in the $\mathrm{pH}$ range from 3.5 to 10 . The diversity measures can be used to evaluate the diversity of resources used by micro-organisms indicating their tolerance to a wide range of environments. The diversity parameters defined on the basis of data obtained through Biolog analysis are presented in Table 4.

A PCA was performed by using PM3B, PM9, and PM10 for a qualitative analysis of the metabolic diversity of both isolates based on the PC score values obtained. Based on the relationships between different substrates, metabolites and strain utilization, the grouping was performed for each individual component. And, for these studies, a separate evaluation was performed for nitrogen source, osmolytes, and $\mathrm{pH}$. The results obtained from nitrogen source (Fig. 5) clarified the metabolic variability of 53.52 and $46.48 \%$ according to the first and second PC values, respectively. A figure for PCA scatters plot of osmolytes (Os) showed the first component of PC analysis accounted for $50.74 \%$ of the total variance and the second $49.26 \%$. Whereas, in the case of $\mathrm{pH}, 53.95$ and $46.06 \%$ of the variance were observed in $\mathrm{PC} 1$ and $\mathrm{PC} 2$, respectively (Fig. 5a-c). 


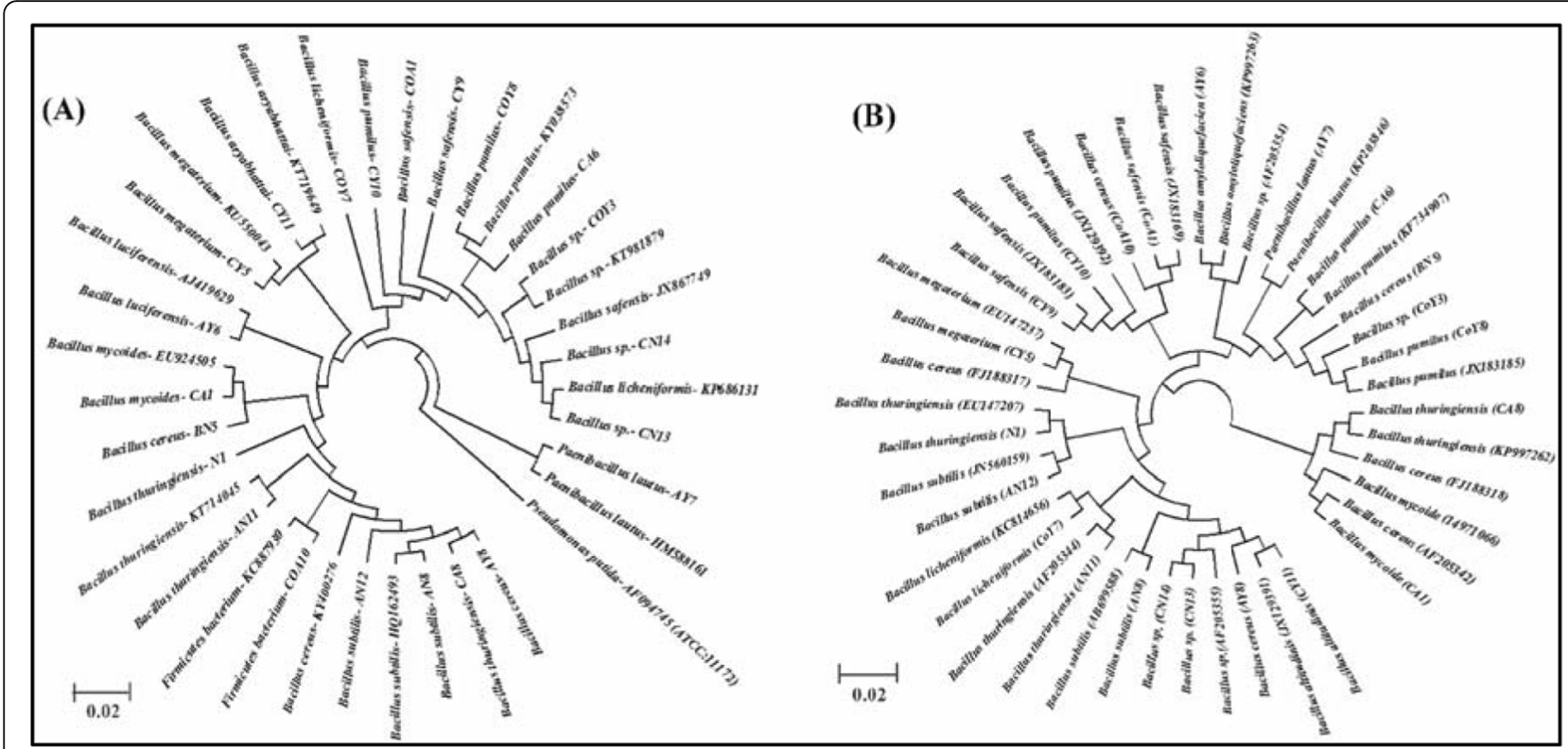

Fig. 2 a-b Phylogenetic tree based on the partial 16S rRNA and rpoB gene sequences of twenty-two potent plant-growth-promoting and nitrogen-fixing Bacillus strains screened from sugarcane. Evolutionary distances were calculated using the UPGMA method. Based on bootstrap analysis of 1000 replications are indicated as percent confidence values for particular branching. Scale bar represents the number of changes per base position and Pseudomonas putida was used as an outgroup

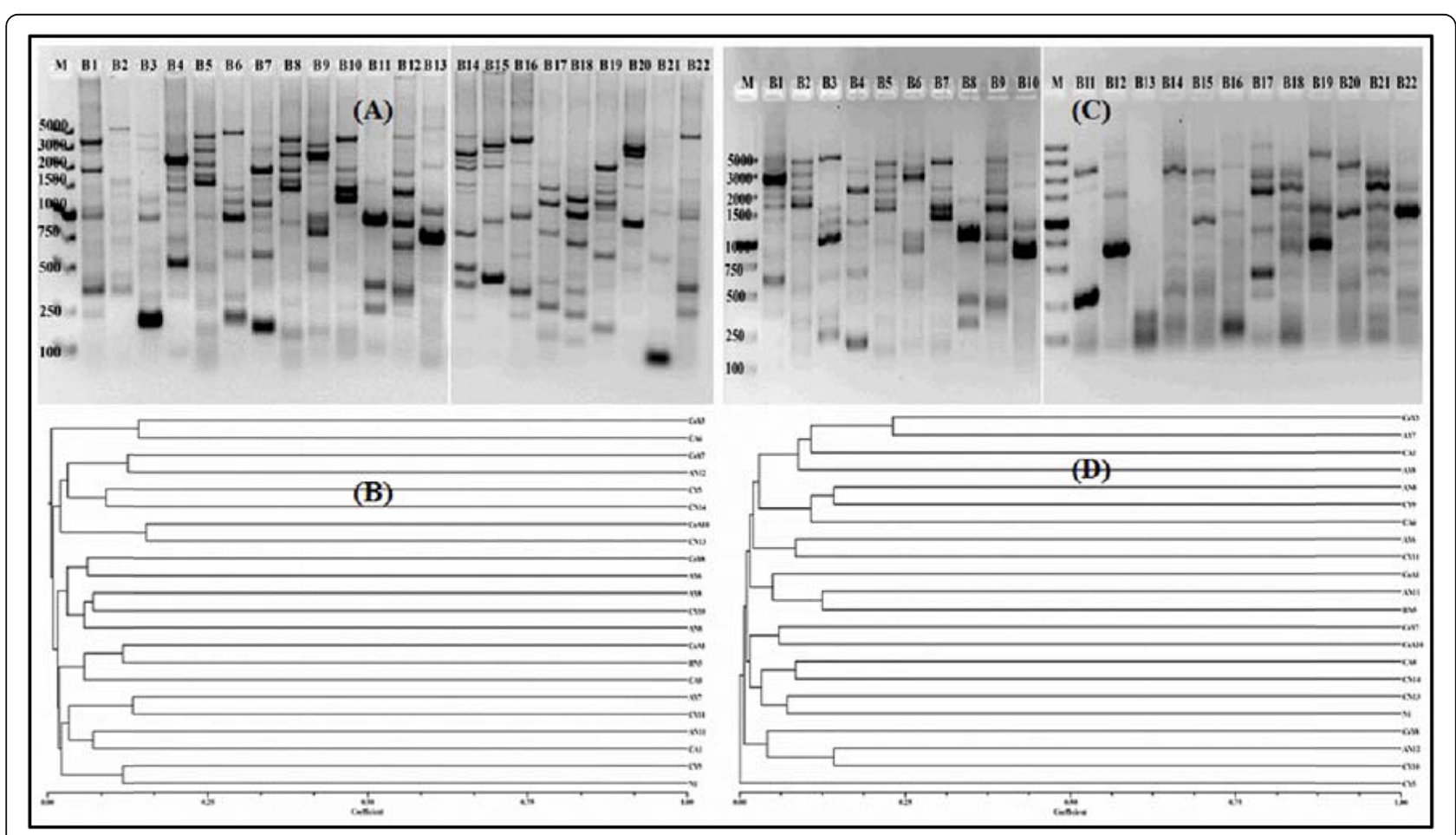

Fig. 3 Genotypic fingerprinting of the screened bacterial isolates from the sugarcane rhizosphere obtained by using genomic DNA. Banding patterns for BOX and ERIC-PCR are shown in $\mathbf{a}$ and $\mathbf{c}$. White space represents the joining of two gels. The dendrogram (b and $\mathbf{d})$ was obtained from the similarity coefficient and clustering was done by using the UPGMA algorithm with the NTSYS software program. Strain Codes: B1. CoY3, B2. CoY7, B3. CoY8, B4. CoA1, B5. CoA10, B6. AY6, B7. AY7, B8. AY8, B9. AN8, B10. AN11, B11. AN12, B12. BN5, B13. CY5, B14. CY9, B15. CY10, B16. CY11, B17. CA1, B18. CA6, B19. CA8, B20. CN13, B21. CN14 and B22. N1. M, molecular size marker from $100 \mathrm{bp}-5 \mathrm{~kb}$ (Takara) 


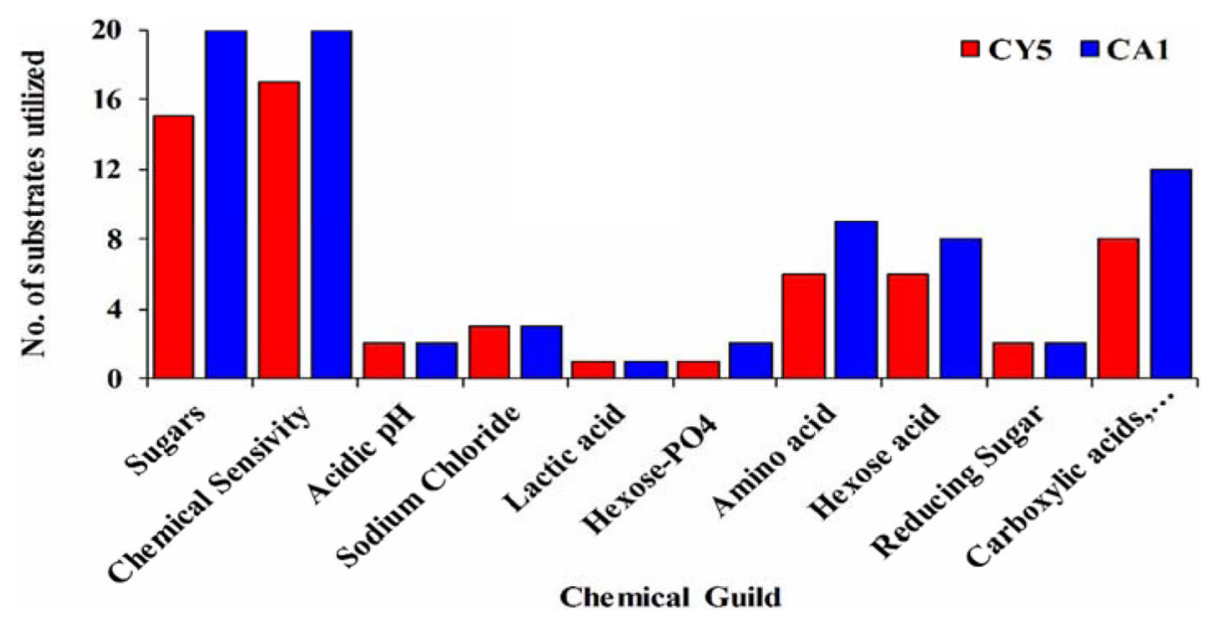

Fig. 4 Pattern of phenotypic profiles in CY5 and CA1 isolates in the presence of different carbon substrate utilization using BIOLOG Phenotype Micro-Array ${ }^{\text {TM }}$ plates GNIII

\section{Colonization pattern of GFP-tagged CY5 and CA1 on sugarcane}

Two isolates selected from the sugarcane rhizosphere, $B$. megaterium (CY5), and B. mycoides (CA1), were used for localization studies using Confocal Laser Scanning Microscopy (CLSM). This technique helped to study plant-microorganism interactions of selected isolates. In this study, both CY5 and CA1 conferred protection against sugarcane pathogens (S. scitamineum, and $C$. paradoxa) produced different PGP traits and showed nitrogenase activity in medium (Tables $1 \& 2$ ). The data in Fig. 6 showed bacterial cells occupying internal plant tissue. These isolates after $72 \mathrm{~h}$ of incubation with GFP pPROBEpTet ${ }^{\mathrm{r}}$-TT showed higher fluorescence, and the increased bacterial cell density could be easily detected under CLSM. The control plants without inoculated isolates showed no fluorescent cells (Fig. 6a-c). However, in the sugarcane stem, the transverse sections of roots and in the mesophyll cells of the leaves intercellular bacterial colonization of single or multiple species of bacteria could be seen in the inoculated plant (Fig. 6d-i). In the leaves, the GFP-tagged isolate was for colonization in roots, mostly root hair zones were overshadowed by the green fluorescence produced from xylem vessels, endodermal junction sites, and cell walls. The CLSM images of root, leaf, and stem showed similar colonization patterns and abundance of both CY5 and CA1.

\section{nifH gene expression determined by qRT-PCR in pots under the greenhouse}

The expression of a nifH gene by the selected diazotroph bacterial isolates in sugarcane varieties GT11 and GXB9 was monitored by qRT-PCR (Fig. 7). The results from the leaf tissue of inoculated GXB9 plants showed the

Table 4 Substrate richness diversity parameters calculated for nitrogen, osmolytes and pH through Biolog for selected strains CY5 (Bacillus megaterium) and CA1 (Bacillus mycoides)

\begin{tabular}{|c|c|c|c|c|c|c|}
\hline \multirow{3}{*}{$\begin{array}{l}\text { Diversity } \\
\text { parameters }\end{array}$} & \multicolumn{6}{|c|}{ Diversity indices measurement through different Biolog Micro-Plates } \\
\hline & \multicolumn{3}{|l|}{ CY5 } & \multicolumn{3}{|l|}{ CA1 } \\
\hline & Nitrogen (PM3B) & Osmolytes (PM9) & $\mathrm{pH}(\mathrm{PM} 10)$ & Nitrogen (PM3B) & Osmolytes (PM9) & $\mathrm{pH}(\mathrm{PM} 10)$ \\
\hline Dominance_D & 0.02512 & 0.01533 & 0.01131 & 0.01551 & 0.01489 & 0.01183 \\
\hline Simpson_1-D & 0.9749 & 0.9847 & 0.9887 & 0.9845 & 0.9851 & 0.9882 \\
\hline Shannon_H & 4.176 & 4.247 & 4.497 & 4.319 & 4.297 & 4.467 \\
\hline Evenness_e^H/S & 0.6783 & 0.7279 & 9.35E-01 & 7.82E-01 & 7.66E-01 & 0.9073 \\
\hline Brillouin & 0.6053 & 2.635 & 2.85 & 0.8634 & 2.099 & 2.291 \\
\hline Menhinick & 21.48 & 11.63 & 9.399 & 11.91 & 8.721 & 8.018 \\
\hline Margalef & 53.02 & 23.4 & 21.27 & 29.89 & 21.5 & 20.63 \\
\hline Equitability_J & 0.915 & 0.9304 & 0.9852 & 0.9462 & 0.9415 & 0.9787 \\
\hline Fisher_alpha & 0.0 & 0.0 & 585.2 & 0.0 & 213.9 & 127.2 \\
\hline Berger-Parker & 0.05006 & 0.01467 & 0.009586 & 0.0154 & 0.01651 & 0.01395 \\
\hline
\end{tabular}



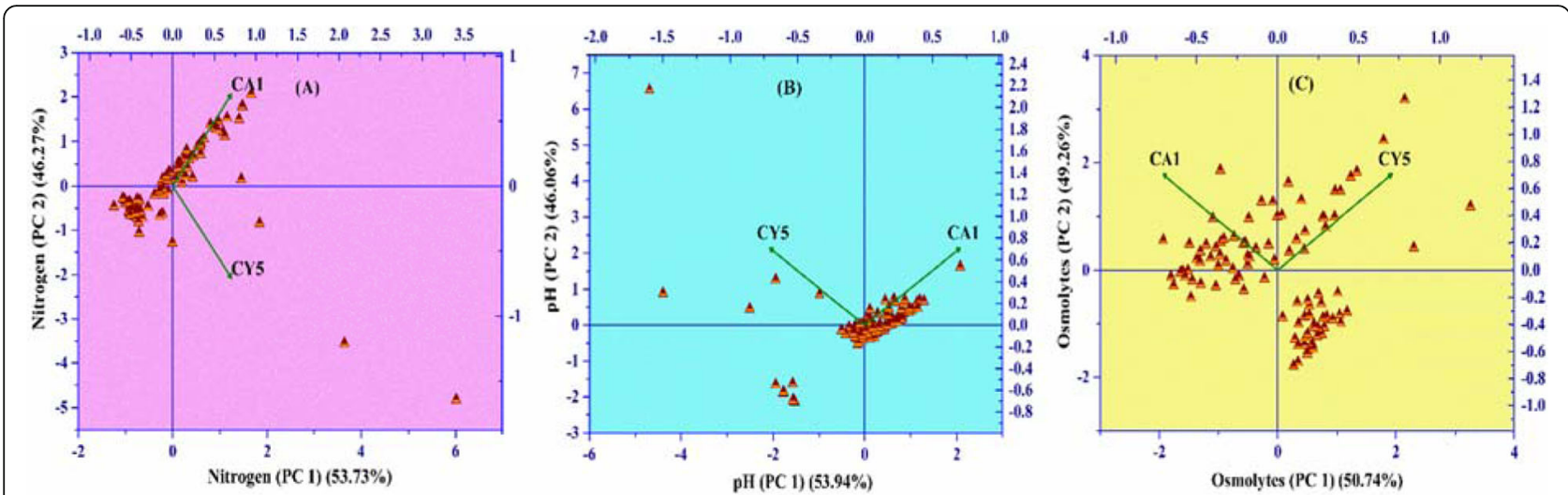

Fig. 5 Graphs of principle component analysis results for Bacillus megaterium (CY5) and Bacillus mycoides (CA1) strains on the basis of BIOLOG ${ }^{(R)}$ micro-plates profile i.e., a nitrogen, $\mathbf{b}$ pH, and $\mathbf{c}$ osmolytes obtained under the different treatments of phenotypic attributes

highest expression of a nifH gene on day 60 postinoculated in both CY5 and CA1 (Fig. 7a), whereas the expression level was higher in GXB9 inoculated with CA1 on day 120 (Fig. 7b). In these studies, nifH gene expression was positively detected following the inoculation of both bacterial isolates in both sugarcane varieties at different time intervals.

\section{Genes expression analysis of CAT, PAL, SOD, CHI, and GLU}

The differential gene expression of catalase (CAT), phenylalanine ammonia-lyase (PAL), superoxide dismutase (SOD), chitinase (CHI) and glucanase (GLU) in leaf tissues at different stages of sugarcane growth was studied by qRT-PCR (Fig. 8). The data showed a significant change in the expression level of all selected five genes in both sugarcane varieties after CA1 and CY5 inoculation. The expression level of CAT increased significantly and equally in both GT11 and GXB9 on days 30 and 60 after planting. The activity of CAT in GT11 increased gradually until day 60 , whereas a similar trend was observed in CA1-inoculated GXB9 until day 30 following planting (Fig. 8a). The PAL expression level showed a significant increase in GT11 on day 60, whereas in GXB9 the increase was observed only on day 30. There was no significant change in the level of PAL expression in GT11 at 30 days and GXB9 at 60 days (Fig. 8b). SOD expression was gradually increased up to 60 days in GT11 for both CY5 and CA1 inoculated strains, whereas, decreased from 30 to 60 days in GXB9 for both inoculated strains (Fig. 8c).

The expression of CHI in GT11 was increased throughout 60 days after planting, while its activity increased for the first 30 days in GXB9 (Fig. 8d). For GT11 and GXB9, the GLU expression increased continuously until day 60, except in CY5-inoculated GXB9 (Fig. 8e).

\section{Percent of ${ }^{15} \mathrm{~N}_{2}$ and $\mathrm{N}$ content in sugarcane}

The concentration of $\mathrm{N}$ content in plant tissues such as leaf, root, and stem was significantly increased with the inoculation of selected isolates (CY5 and CA1) in both sugarcane varieties (GT11 and GXB9) as compared with the control (uninoculated). For GT11, the maximum increase in total $\mathrm{N}$ concentration was observed in root samples for plants inoculated with both isolates compared with the control (Fig. 9a). Whereas for GXB9, compared with the control, CY5 inoculation results in more $\mathrm{N}$ concentration than that with $\mathrm{CA} 1$ in all samples (Fig. 9b).

To estimate the proportion of $\mathrm{N}$ in sugarcane plant parts derived from the atmosphere, the plant growth medium was equally tagged with ten mg of $\mathrm{H}_{4} \mathrm{SO}_{4}$ per kilogram of soil. Our results showed that strain CY5 fixed more $\mathrm{N}$ in root and stem tissues whereas, less $\mathrm{N}$ in leaf tissues of GT11 variety as compared to CA1 strain. However, in the case of GXB9 variety, CA1 fixed more $\mathrm{N}$ in all plant parts (leaf, stem, and root) than strain CY5 (Fig. 9c-d). Consequently, the availability of $\mathrm{N}$ in inoculated plants allowed improved growth and development in soil-grown plants.

\section{Discussion}

An important objective of research on rhizosphere microbes that fix nitrogen is to extend biological nitrogen fixation as a significant source of nitrogen for nonleguminous crops. It is important to identify a nitrogenfixing micro-organism in a major agricultural crop like sugarcane. In addition, BNF microorganisms reduce the cost of sugarcane production [5]. In Brazil sugarcane is cultivated with a very low amount of $\mathrm{N}$ inputs suggesting the occurrence of BNF [25]. In this work, the evidence of BNF in B. megaterium (CY5), and B. mycoides (CA1) is well established. Ambrosini et al. [48] previously studied Bacillus mycoides B38 V, which produces various PGP traits and biocontrol activity against 

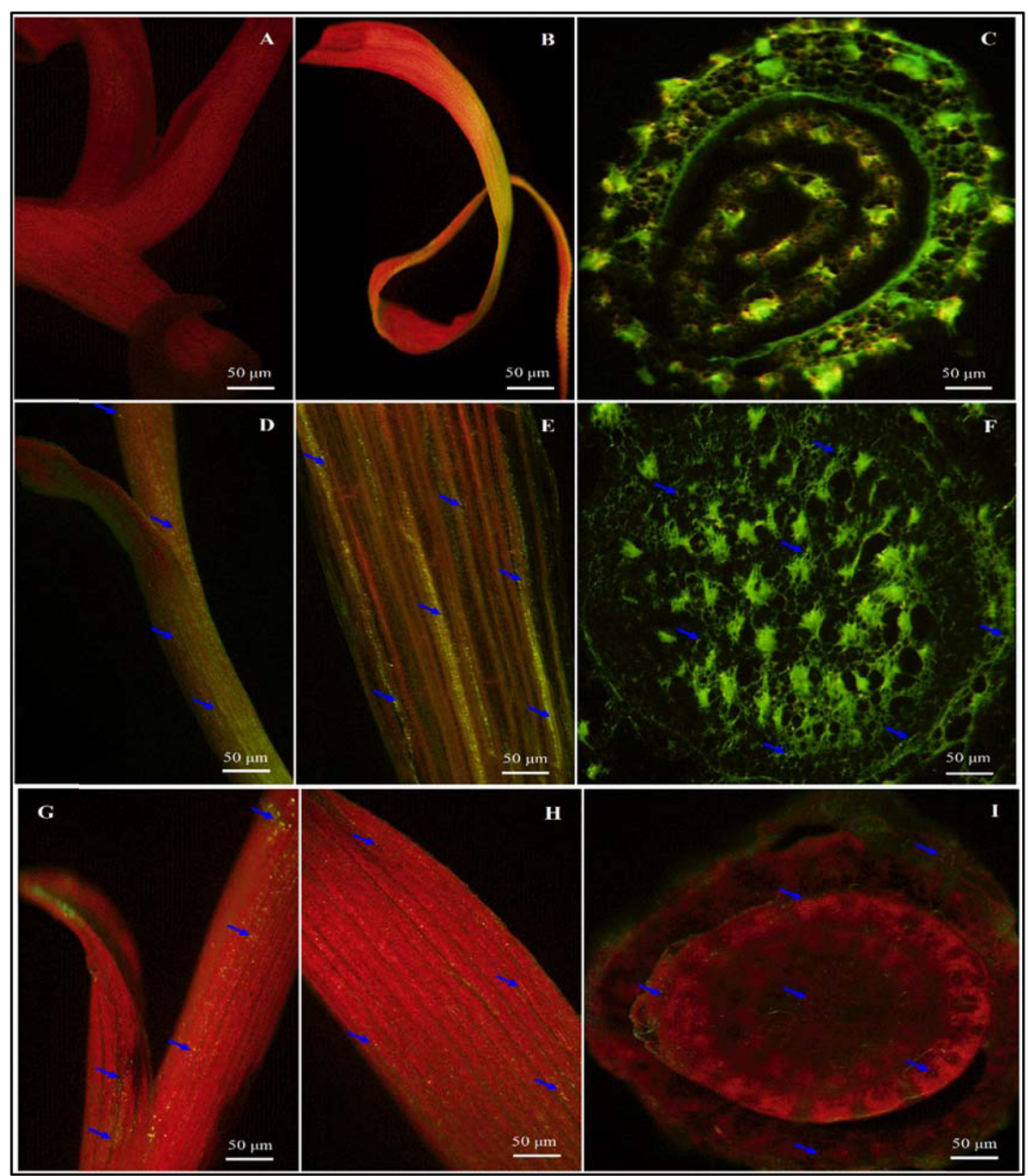

Fig. 6 Fluorescence (GFP) micrographs of sugarcane plant colonized by GFP-tagged Bacillus megaterium (CY5) and Bacillus mycoides (CA1) leaf, stem, and the root of micropropagated plantlets of sugarcane variety GT11. Confocal laser scanning microscopic images present bacterial in green and red dots of auto-fluorescence in everywhere of plant parts respectively. (A-C) Control sugarcane plant parts and (D-I) Sugarcane plant parts inoculated with GFP tagged bacterial strains at 500-530 nm. On the surface of roots, junction area, around the whole root, stem, and leaf. Bacterial cells are indicated with blue arrowheads in single or clustered of bacteria. D-F represent CY5, and G-I represents CA1 strain with bar $50 \mu \mathrm{m}$

Sclerotinia scleratiorum isolated from sunflower. Here, we confirmed that Bacillus mycoides is the nitrogenfixing as well as plant growth-promoting bacteria in sugarcane. Members of some Bacillus spp. showed PGP traits and $\mathrm{N}$-fixing ability, directly affects the plant growth and development $[49,50]$.

Soil micro-organisms are essential for biogeochemical cycles, colonizing the plant root, improving soil fertility and plant health and increasing crop production [51, 52]. In this specific study, we focused on Bacillus genus isolated from the sugarcane rhizosphere and characterized them for PGP traits, in vitro antifungal activities as well as nitrogen-fixing activity. A total of 22 Bacillus isolates were identified following16S rRNA and rpoB gene- based phylogenetic analysis. All the 22 strains isolated in the present study were selected on the basis of PGP, nitrogenase, biocontrol of pathogens, etc. The strains $\mathrm{Ba}$ cillus megaterium (CY5) and Bacillus mycoides (CA1) were the most promising. Therefore, the antagonistic efficacy test can be used as a regular test for screening biocontrol agents and shows a cumulative result of all mechanisms for biocontrol [7, 29]. Nitrogen-fixing bacterial genera especially Bacillus, Pseudomonas, and Enterobacter, are known to solubilize phosphate compounds present in the soil. Among the 22 bacterial isolates, $18(81.8 \%)$ isolates displayed to phosphate solubilization property by forming clear zones in the plates [7, 30]. Another PGP trait of Bacillus species was 

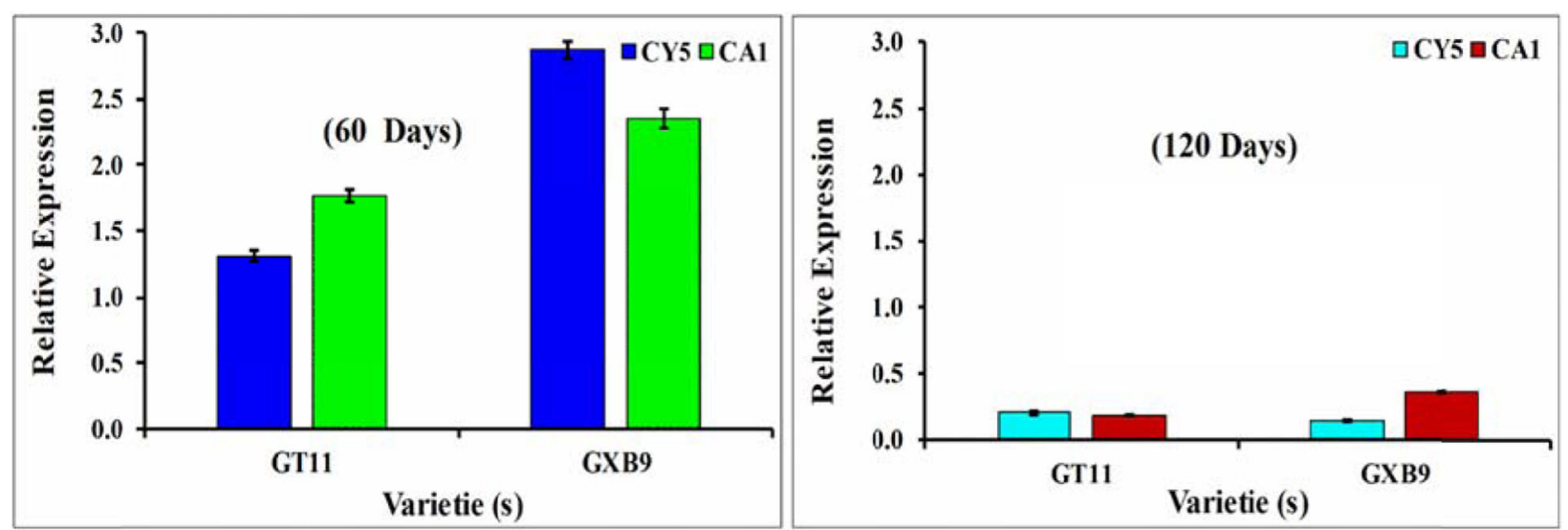

Fig. 7 Analysis of inoculated potent strains Bacillus megaterium (CY5) and Bacillus mycoides (CA1) on the nifH expression patterns in two sugarcane varieties (GT11 and GXB9) at 60 and 120 days through qRT-PCR. Data were normalized to the GAPDH expression level. All the data points are the means \pm SE $(n=3)$

the activity of siderophore, and it has been recommended that siderophores are involved in plant protection $[53,54]$. The qualitative test results showed 59.1 and $18.2 \%$ of Bacillus strains had ammonium and HCN production ability. Also, all selected screened strains played an important role in biocontrol of S. scitamineum and C. paradoxa pathogens.

Smut, caused by S. scitamineum is a major disease of sugarcane [55], which causes significant yield loss of sugarcane production in Guangxi, China. The average smut infection rate is over $10 \%$ and might reach over $50 \%$ in some regions in China [55]. Pineapple disease is another common disease in all sugarcane growing regions in China, caused by $C$. paradoxa. Therefore, preventing these diseases, by non-chemical means is now a research priority in China. Bacillus strains produced ammonia when grown in nitrogen sources and ammonia accumulating strains supply nitrogen to the host plant and support plant biomass production [56].

The method to examine the quantitative amount of PGPR associated with sugarcane is culture-dependent. A number of bacterial strains expressing ACC deaminase have been isolated in laboratory conditions worldwide and reported their PGPR activity [57, 58]. Many PGPR bacteria stimulate plant growth through the activity of ACC deaminase by reducing plant ethylene levels. Nascimento et al. [59] reported that the ACC deaminase shows various roles in microorganism's developmental processes along with plant growth promotion abilities and also proposed the ACC deaminase belongs to an extensive group of pyridoxal phosphate-dependent enzymes based on protein sequence and phylogenetic analysis. And, the best ACC-utilizing bacterial isolates are from the genus Burkholderia and Pseudomonas isolated from sugarcane [60,61]. Quantitatively, only ten (45.45\%) studied strains showed significant ACC deaminase activity, with $\mathrm{CY} 5$ and $\mathrm{CA} 1$ recording the highest activity. The bacterial strains producing IAA might increase root growth and help develop lateral roots which would increase nutrient uptake from the rhizosphere [62]. We found that all the Bacillus strains were able to produce IAA in the range from 35.01 to $130.96 \mu \mathrm{g} \mathrm{m}^{-1}$. Also, all the selected strains showed nitrogenase activity and they were confirmed as nitrogenfixing bacteria, similar to what was observed previously in. Bacillus mycoides B38 V, and Bacillus megaterium $[30,48]$.

In this study, we have also examined a molecular method for examining the nitrogen-fixing genes in all the selected strains. For the amplification of the nifH gene, several primers were used based on its nucleotide sequences, yet the nifH gene was amplified in only six strains. It has been reported that the amplification of the nifH gene is useful for confirming the potential strains showing nitrogen fixation [63]. The lack of nifH gene amplification does not imply that the isolates are not capable of BNF since the nucleotide sequences of the nifH gene in some Bacillus species may be significantly different from others [64]. Genomic diversity of Bacillus strains in this study showed considerable similarity to those reported earlier [7]. Genetic diversity studies of bacterial species isolated from sugarcane using PCRbased methods are limited. Versalovic et al. [65] described a method of bacterial fingerprinting to examine the strain-specific banding patterns for PCR amplification of repetitive DNA elements presented in entire bacterial genomes. The dendrogram obtained from the cluster analysis of BOX and ERIC-PCR fingerprints provided a complete classification of the species exhibiting biological nitrogen fixation.

Out of all the screened strains, two strains (CY5 and CA1) were characterized using BIOLOG ${ }^{(R)}$ phenotype 


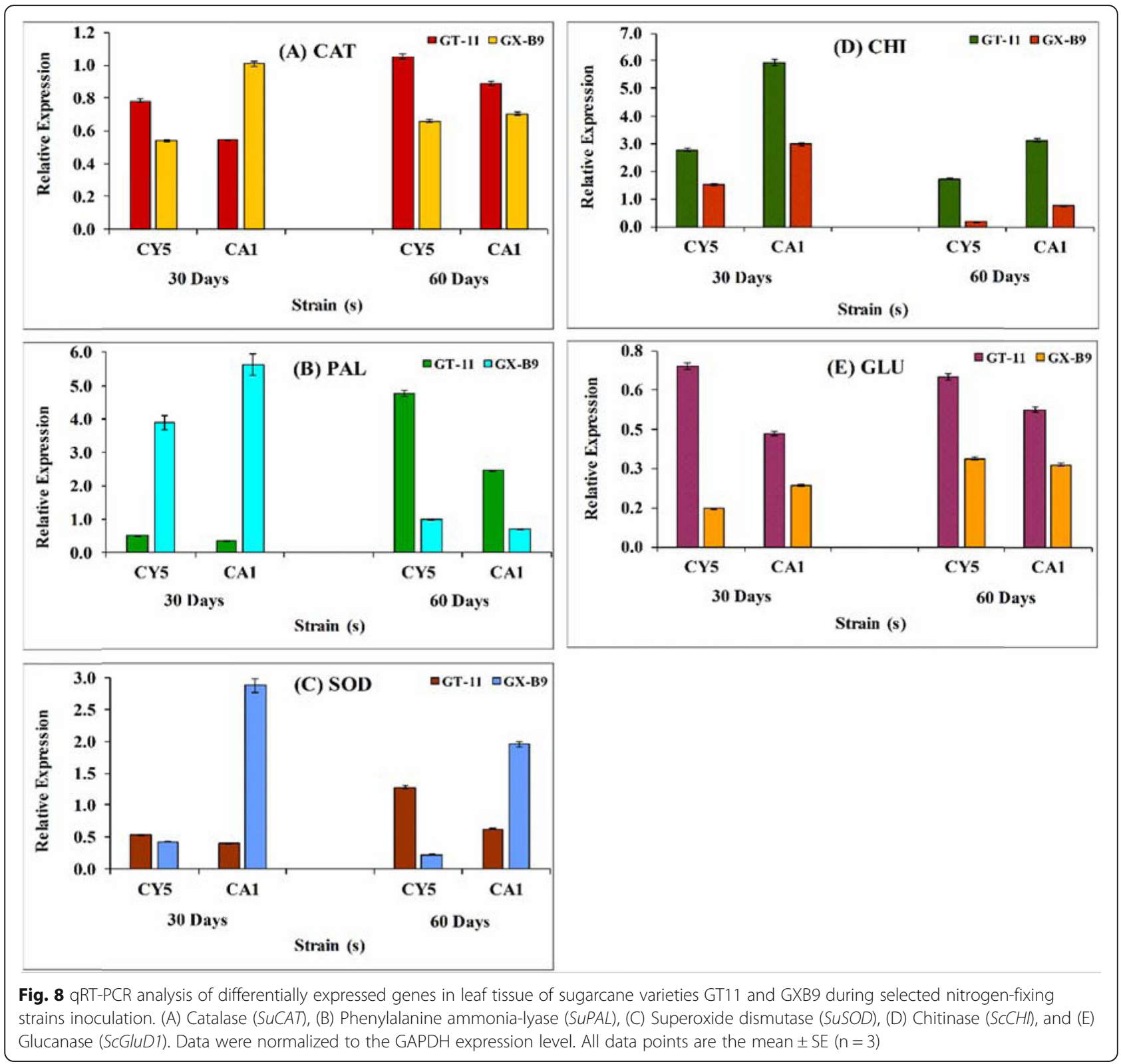

microarray assays, localization studies using GFP marker, nifH gene expression using qRT-PCR and ${ }^{15} \mathrm{~N}_{2}$ isotope dilution assay in sugarcane plants inoculated with CY5 and CA1. The pattern of metabolic profiling of CY5 and CA1 showed that they use a variety of metabolic substrates (Fig. 4). Wielbo et al. [66] proposed that strains with wide metabolite tolerance were more effective players in host plant nodulation. In this study, the strain CA1 was more metabolically diverse than CY5, suggested that CA1 might be more effective in terms of plant growth and development. The metabolic properties of an organism might play a role in survival to establish successful host assemblage and to promote plant growth and establishment [67].
To examine the effect of bacterial strains on sugarcane colonization capability CY5 and CA1 were genetically tagged with GFP and the amount of colonization was observed by using CLSM. The uninoculated plants after $72 \mathrm{~h}$ of incubation showed no fluorescent bacterial colony, whereas, in the plants inoculated with the isolates, it was observed that bacterial cell density had increased, and fluorescent cells were detected and all over the plant organs, including roots, stems, and leaves. Both strains colonized the sugarcane after inoculated independently. Fluorescence due to the GFP-tagged bacterial colonization was detected in all the sugarcane plant parts. Similarly, in the sugarcane plant, fluorescent cells of GFP tagging can be observed on sugarcane roots and 

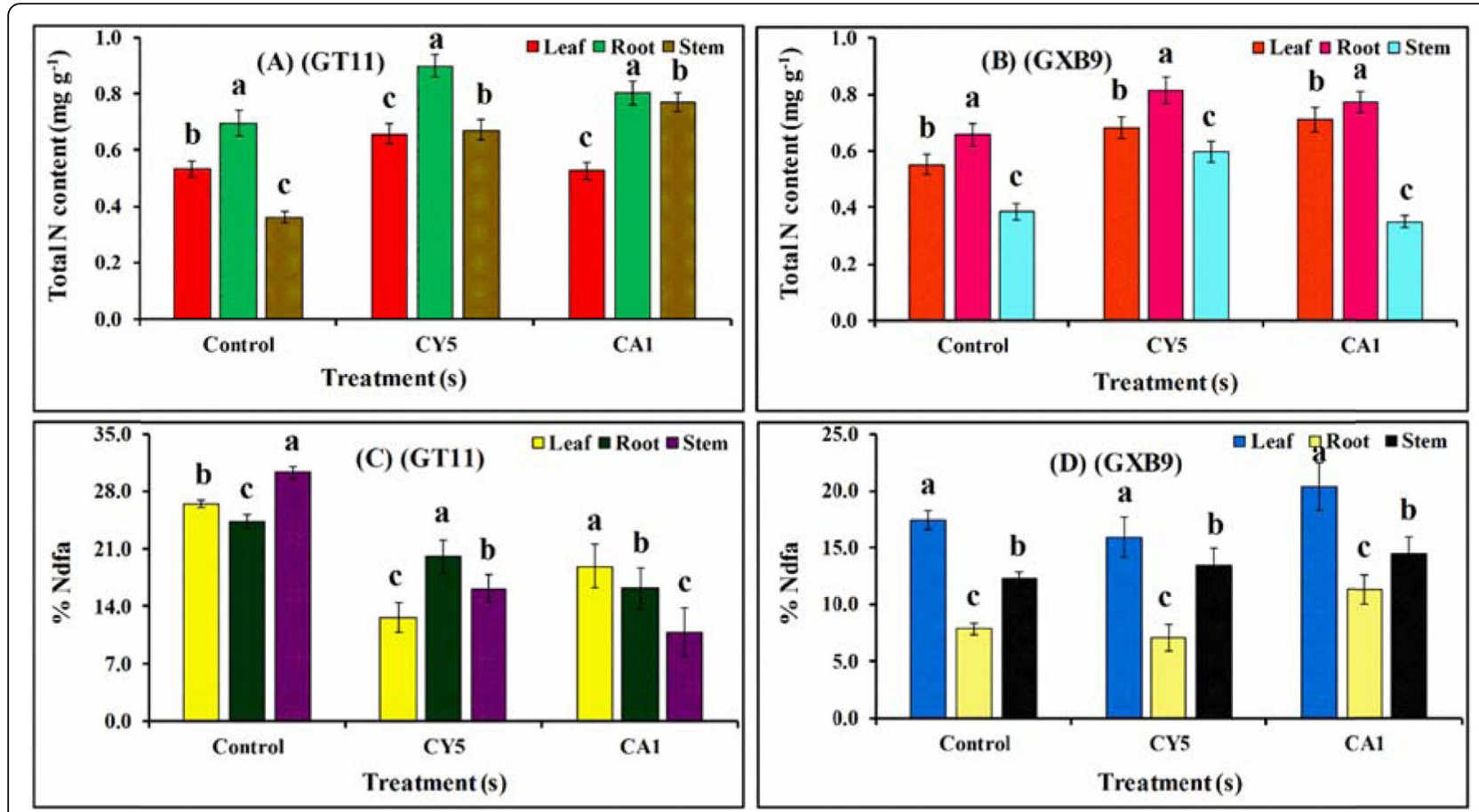

Fig. 9 Effect of inoculation of strains Bacillus megaterium (CY5) and Bacillus mycoides (CA1) on percent ${ }^{15} \mathrm{~N}$ and $\mathrm{N}$ parameters for dry biomass of two sugarcane varieties (GT11 and GXB9). The columns represent the mean of the data for each treatment and bars represent the standard error

leaves but the micro-organisms and their pattern of colonization were different $[7,68]$.

We determined the amount of nifH gene expression for selected strains in sugarcane by qRT-PCR. The nifH gene expression through mRNA of diazotrophs indicated the level of biological $\mathrm{N}_{2}$ fixation activity, and our results showed both CY5 and CA1 strains, as well as control, expressed nitrogen fixation activity in both sugarcane varieties at different levels. The qRT-PCR method is highly sensitive and specific [69] and suitable for the detection of mRNA transcriptions of micro-organisms at low densities in different plant tissues or experimental samples. The expression profile of important plant development and defense-related enzymes, specifically CAT, PAL, SOD, CHI and GLU was compared by RTqPCR technique in both sugarcane plants at 30 and 60 days of post-inoculation with $\mathrm{CY} 5$ and CA1 strains. Similar to the earlier reports a positive response of antioxidant enzymes (CAT, SOD, and PAL) at different developmental stages in sugarcane against smut disease resistance was observed [70]. The expression of several catalase genes is regulated in response to numerous environmental oxidative stimuli in sugarcane [71] and different developmental stages in maize [72, 73]. Additionally, the positive response of SOD and PAL supports the contention that Bacillus species such as CY5 and CA1 help sugarcane tolerate various oxidative stresses [74, 75]. Plant beta-1,3-glucanase and chitinases are the PR proteins, extensively distributed in higher plant roots, stems, and flowers [76-87], and the expression of these proteins has been controlled mostly during stress conditions such as pathogen infection [78]. The expression of beta-1,3-glucanase and chitinase genes has been reported in various physiological and developmental processes of plants [79], like seed and pollen germination [80], flower development and fruit ripening [81].

${ }^{15} \mathrm{~N}_{2}$ isotope dilution and $\mathrm{N}$ balance trials with different cultivars of sugarcane specify their ability to obtain substantial quantities of nitrogen from atmospheric $\mathrm{N}_{2}$ through biological nitrogen-fixing micro-organisms [82]. In this study, our results of ${ }^{15} \mathrm{~N}_{2}$ isotope dilution method and $\mathrm{N}_{2}$ assimilation experiments proposed a similar role of biological nitrogen fixation by micro-organisms in sugarcane plants.

\section{Conclusions}

In summary, the present study indicates the occurrence of various strains of Bacillus genus as plant-growth promoting and nitrogen-fixing bacteria in the sugarcane rhizosphere. The use of effective nitrogen-fixing microorganisms is an opportunity for improving crop production in addition to maintaining soil structure and fertility. And, all those isolated bacteria showed various PGP traits, nitrogenase activity, and disease resistance in response to different pathogens. Both strains, B. megaterium (CY5), and B. mycoides (CA1) may play an 
important role in sugarcane crop protection, adaptation to environmental stresses and provision of nutrients.

\section{Methods \\ Descriptions of the study site, and soil physico-chemical analysis}

The aim of soil testing is to determine the nutrient of the study site. The study site is located in an experimental field of Guangxi University, Nanning, China at latitude $22^{\circ} 49^{\prime} 1.21^{\prime \prime} \mathrm{N}$, longitude $108^{\circ} 21^{\prime} 59.55^{\prime \prime} \mathrm{E}$ and an elevation between 70 and $500 \mathrm{~m}$ above sea-level. It has a warm, humid subtropical climate with an annual average temperature of $21.7^{\circ} \mathrm{C}\left(21-33^{\circ} \mathrm{C}\right)$, and rainfall varied between $1000 \mathrm{~mm}$ to 2800 . Soil samples were randomly collected from the sugarcane field in April 2015 and stored at $4{ }^{\circ} \mathrm{C}$. The crushed soil samples were analyzed for physical and chemical properties. The electrical conductivity (EC) of rhizosphere soil ranged from 0.00871 to $0.0111 \mathrm{Sm}^{-1}$, and it depends on the amount of moisture and the size, and texture of soil particles. The water content was varied from 5.13 to $6.18 \%$, and the $\mathrm{pH}$ ranged from 6.0 to 6.70 . The amount nitrogen, phosphorus, and potassium in the test soil were 0.60, 0.46 and $14.26 \mathrm{~g} \mathrm{Kg}^{-1}$ respectively. The level of other macro and micronutrients in the sugarcane rhizosphere are presented in Additional file 5 (Table S2).

\section{Isolation of nitrogen-fixing bacteria}

Five, six months old healthy cultivated sugarcane plants were randomly collected from our experimental field of Sugarcane Research Institute, Guangxi Academy of Agricultural Sciences, Nanning, China. No permissions were required for the collection of sugarcane plant samples in this study. Root-adhered soil was collected and mixed well and then stored at $4{ }^{\circ} \mathrm{C}$ for further analysis. Root debris was removed by sieving the soil through a $2 \mathrm{~mm}$ mesh. Ten grams of soil sample was suspended in $90 \mathrm{~mL}$ of saline water and agitated in an orbital shaker set at $100 \mathrm{rpm}$ and $30 \pm 2{ }^{\circ} \mathrm{C}$ for $30 \mathrm{~min}$. Different bacterial species present in the soil suspension were isolated as described earlier [29]. Nitrogen-fixing bacteria were isolated by using five different media JNFb medium, LGI Medium [83, 84], Ashbey medium (Hi-Media), Yeast Mannitol Agar (Hi-Media), and Nutrient Agar (HiMedia) (Additional file 6: Table S3). The colonies of dissimilar morphotypes appeared in the culture were purified and stored for further studies.

\section{Identification of isolates with antifungal and plant growth promotion properties}

All isolates were tested for their in vitro antifungal activity by dual culture method on PDA: NA (1:1) agar plates with two sugarcane pathogens $S$. scitamineum, and $C$. paradoxa. A disk of $5 \mathrm{~mm}$ diameter was cut from an actively growing culture in the PDA plate and it was placed at the center of the PDA: NA plates. The bacterial isolates were grown in nutrient broth at a concentration of $10^{6}$ cell $\mathrm{mL}^{-1}$ and they were streaked on the plate approximately $3 \mathrm{~cm}$ from the center where pathogen disk is located $[29,85]$. The cultures were then incubated at $28 \pm 2{ }^{\circ} \mathrm{C}$ for five days or till the fungal mycelia were fully grown in the control plate. Pathogen without bacterial strain was used as a control. The antifungal activity was assessed by determining the growth inhibition against the test pathogen. The Percentage of inhibition was calculated according to Singh et al. [29]. The isolates showing $\geq 50 \%$ inhibition of mycelial growth was considered as promising biocontrol agents.

The plant growth promotion potential of all the selected isolates was assessed by standard procedures that measure phosphate solubilization [52] and the production of siderophore [86], $\mathrm{HCN},[87]$ and ammonia production [88]. IAA production by the isolates was estimated spectrophotometrically following the method described by Glickmann and Dessaux [89].

\section{1-Aminocyclopropane-1-carboxylate deaminase assay}

All isolates were screened for ACC deaminase activity by using nitrogen-free Dworkin and Foster (DF) medium [90]. Medium without ACC was used as a negative control, whereas two positive controls, i.e. medium with ammonium sulfate $\left[\left(\mathrm{NH}_{4}\right)_{2} \mathrm{SO}_{4}\right](0.2 \% \mathrm{w} / \mathrm{v})$ and those with ACC ( $3 \mathrm{mM})$ were also used, and the cultures were incubated at $30 \pm 2{ }^{\circ} \mathrm{C}$ for $3-5$ days. The strains grown on ACC plates were further selected and $a c d S$ gene amplification was observed with degenerate primers and the conditions were followed by Li et al. [91]. The ACC deaminase activity was quantified according to Honma and Shimomura [92].

\section{Acetylene reduction assay}

Each bacterial isolate was examined for nitrogen-fixing ability through the acetylene reduction assay (ARA) method [93]. All isolates were inoculated in a $25 \mathrm{~mL}$ flask comprising $10 \mathrm{~mL} \mathrm{JNFb} \mathrm{(Additional} \mathrm{file} \mathrm{6)} \mathrm{medium}$ and incubated for 3 days at $30 \pm 2{ }^{\circ} \mathrm{C}$. Inside air from the tubes is replaced with $5 \mathrm{~mL}$ of acetylene through a syringe and the tubes were incubated for $24 \mathrm{~h}$ at $30 \pm 2{ }^{\circ} \mathrm{C}$ [7]. The column (DB-1701, Agilent, Santa Clara, USA) temperature was set at $80^{\circ} \mathrm{C}$, whereas flame ionization detector and injector temperature were $110^{\circ} \mathrm{C}$, with carrier gas nitrogen at a flow rate of $35 \mathrm{~mL} \mathrm{~min}^{-1}$. A gas sample from the tube $(0.5 \mathrm{~mL})$ was inserted into the GC-17A gas chromatograph (Shimadzu, Kyoto, Japan) and the peak heights were measured and to compute ethylene production in samples. The total protein concentration of each sample tube was estimated by the protein assay kit (Solarbio, Life Sciences, Beijing). 


\section{DNA extraction and partial sequencing of $16 \mathrm{~S}$ rRNA and rpoB genes}

A pure culture of bacteria was grown in Luria-Bertani broth for 24-36 h on a rotary incubator maintained at $32 \pm 2{ }^{\circ} \mathrm{C}$ and $150 \mathrm{rpm}$. DNA was extracted from $1.5 \mathrm{~mL}$ of pure culture using a DNA isolation kit (CWBIO, Beijing-China) according to the manufacturer's instructions. The quantity and integrity of the extracted DNA were determined by electrophoresis $(0.8 \%)$ and by spectrophotometry, using Nanophotometer (Pearl, Implen3780).

To amplify the $16 \mathrm{~S}$ rRNA and $r p o B$ gene, primer pairs PA-F and PH-R for the 16S rRNA gene [96 and rpoB-F and rpoB-R for $r p o B$ gene [94] were used (Table 5). The polymerase chain reaction (PCR) was performed for $16 \mathrm{~S}$ rRNA gene with a heated lid included in the initial denaturation at $95^{\circ} \mathrm{C}$ for $5 \mathrm{~min}, 30$ cycles of denaturation at $95^{\circ} \mathrm{C}$ for $1 \mathrm{~min}$, annealing at $55^{\circ} \mathrm{C}$ for $1 \mathrm{~min}$, extension at $72^{\circ} \mathrm{C}$ for $1 \mathrm{~min}$ and $r p o B$ gene $95^{\circ} \mathrm{C}$ for $3 \mathrm{~min}$, 35 cycles at $95^{\circ} \mathrm{C}$ for $20 \mathrm{~s}, 55^{\circ} \mathrm{C}$ for $30 \mathrm{~s}$, and $72^{\circ} \mathrm{C}$ for $1.5 \mathrm{~min}$ extension and final extension for both genes at $72{ }^{\circ} \mathrm{C}$ for $5 \mathrm{~min}$. All amplified products were purified by PCR purification kit (Bioflux) and sequenced (Sangon Biotech, Shanghai, China).

\section{Phylogenetic analysis}

To verify the identities of the bacterial isolates and determine their evolutionary relationships, the $16 \mathrm{~S}$ rRNA and rро $B$ gene sequences with essential reference sequences were sourced from the NCBI GenBank database. The multiple sequences were aligned by ClustalW [100] and the BlastN search program was performed to compare the sequences. The $16 \mathrm{~S}$ rRNA and $r p o B$ genes were subjected to phylogenetic analysis using molecular evolutionary genetics analysis (MEGA) software (version 7.0) [101], and the unweighted pair group method with arithmetic mean (UPGMA) in a Kimura two-parameter model [102]. The bootstrap analysis was carried out by the Felsenstein method using 1000 pseudoreplication [103].

\section{Amplification, cloning, and sequencing of the nifH gene} Using total DNA as a template, the nifH gene was amplified by polymerase chain reaction (PCR) using primers PolF and PolR ([97]; Table 5). The PCR was performed as described earlier [7]. The PCR product was gel extracted, purified and cloned (pMD ${ }^{\odot} 18$-TVector) following the manufacturer's (TaKaRa, Japan) instructions. The recombinant colonies grown on Luria-Bertani agar plates containing $50 \mu \mathrm{g} \mathrm{mL}^{-1}$ ampicillin were identified by colony PCR. The cloned PCR products were sequenced (Sangon Biotech, Shanghai, China) to establish the nifH gene identity.

Genetic characterization of isolates by BOX and ERIC-PCR To determine the genetic diversity of selected isolates, total DNA isolated were fingerprinted by BOX-PCR and

Table 5 PCR primers used for species identification, molecular characterization, and gene expression

\begin{tabular}{|c|c|c|c|c|}
\hline Target Gene & $\begin{array}{l}\text { Primer } \\
\text { Name }\end{array}$ & Nucleotide Sequence $\left(5^{\prime}\right.$------- $\left.\rightarrow 3^{\prime}\right)$ & Product Size (bp) & Reference \\
\hline $16 S$ & $\begin{array}{l}\text { PA-F } \\
\text { PH-R }\end{array}$ & $\begin{array}{l}\text { AGAGTTGGATCCTGGCTCAG } \\
\text { AAGGAGGTGATCCAGCCGCA }\end{array}$ & $1300-1500$ & [95] \\
\hline$r p o B$ & $\begin{array}{l}\text { RPO-F } \\
\text { RPO-R }\end{array}$ & $\begin{array}{l}\text { ATCGAAACGCCTGAAGGTCCAAACAT } \\
\text { ACACCCTTGTTACCGTGACGACC }\end{array}$ & $>1100$ & [94] \\
\hline $\mathrm{BOX}$ & BOX A1R & CTACGGCAAGGCGACGCTGACG & $50-5000$ & [96] \\
\hline ERIC & $\begin{array}{l}\text { ERIC-1 } \\
\text { ERIC-2 }\end{array}$ & $\begin{array}{l}\text { ATGTAAGCTCCTGGGGATTCAC } \\
\text { AAGTAAGTGACTGGGGTGAGCG }\end{array}$ & $50-5000$ & \\
\hline \multicolumn{5}{|l|}{ RTq-PCR Primers } \\
\hline $\mathrm{NifH}$ & $\begin{array}{l}\text { Pol-F } \\
\text { Pol-R }\end{array}$ & $\begin{array}{l}\text { TGCGAYCC-SAARGCBGACTC } \\
\text { ATSGCCATCATYTCRCCGGA }\end{array}$ & RTq-PCR & {$[97]$} \\
\hline Glyceraldehyde 3-phosphate dehydrogenase & $\begin{array}{l}\text { GAPDH-1 } \\
\text { GAPDH-2 }\end{array}$ & $\begin{array}{l}\text { CTCTGCCCCAAGCAAAGATG } \\
\text { TGTTGTGCAGCTAGCATTG }\end{array}$ & RTq-PCR & [98] \\
\hline SUPAL & $\begin{array}{l}\text { PAL-F } \\
\text { PAL-R }\end{array}$ & $\begin{array}{l}\text { CTCGAGGAGAACATCAAGAC } \\
\text { GTGATGAGCTCCTTCTCG }\end{array}$ & RTq-PCR & [74] \\
\hline SUCAT & $\begin{array}{l}\text { CAT-F } \\
\text { CAT-R }\end{array}$ & $\begin{array}{l}\text { CTTGTCTGGAGCACATACACTTGGA } \\
\text { TTCTCCGCATAGACCTTGAACTITG }\end{array}$ & RTq-PCR & [72] \\
\hline SUSOD & $\begin{array}{l}\text { SOD-F } \\
\text { SOD-R }\end{array}$ & $\begin{array}{l}\text { TाTGTCCAAGAGGGAGATGG } \\
\text { CTTCTCCAGCGGTGACATTT }\end{array}$ & RTq-PCR & [75] \\
\hline ScChi & $\begin{array}{l}\text { ScChi-QF } \\
\text { ScChi-QR }\end{array}$ & $\begin{array}{l}\text { ACGGCTACGGCGACAACA } \\
\text { GTCCGCTGACCAGATGAAGAG }\end{array}$ & RTq-PCR & [71] \\
\hline ScGluD1 & $\begin{array}{l}\mathrm{D}-\mathrm{QF} \\
\mathrm{D}-\mathrm{QR}\end{array}$ & $\begin{array}{l}\text { TGCTACTTCTTATCCACCCTCTG } \\
\text { CGTTGACATAGAAAGGTGAGCC }\end{array}$ & RTq-PCR & [99] \\
\hline
\end{tabular}


ERIC-PCR [29] using the primers and the conditions listed in Table 5, and Additional file 7 (Table S4), respectively. The amplified bands were separated by gel electrophoresis (1.5\% agarose) and the gels were imaged by the BIORAD gel documentation system.

\section{Phenotype microarray assays}

Among all the screened isolates CY5 and CA1 were the most potent $\mathrm{N}$-fixing strains on the basis of PGPs as well as nitrogenase activity. Thus, both were selected for further experiments. Phenotype microarray was conducted using Biolog microplates, a tetrazolium-based growth assay developed by Biolog Incorporated (Biolog, Inc., Hayward, CA). The potential strains CY5 and CA1 were assayed on microplates GENIII, PM3B, PM9 and PM10, testing for different substrates such as several carbon and nitrogen sources, and tolerance to different osmotic and $\mathrm{pH}$ stresses [104]. The inoculum of microplates was prepared as described [7]. All the microplates were incubated for $72 \mathrm{~h}$ at $30 \pm 2{ }^{\circ} \mathrm{C}$ for tetrazolium color development. After incubation, the readings were obtained using an automated BIOLOG ${ }^{(\mathrm{R})}$ Micro-Station Reader according to the manufacturer's instructions. The microbial growth was evaluated using optical density measurements at $590 \mathrm{~nm}$ after $72 \mathrm{~h}$ incubation.

\section{Genetic transformation of strains with green fluorescent protein \\ Plasmid transformation}

The pPROBE-pTet ${ }^{\mathrm{r}}$-TT plasmid containing the green fluorescent protein (GFP) gene and tetracycline resistance gene (provided by State Key Laboratory of Subtropical Bioresources Conservation and Utilization, Guangxi University, Nanning, China) was transferred to Bacillus strains (CY5 and CA1) by biparental mating using Escherichia coli strain TG1 as the donor and DH5 $\alpha /$ pRK2013 as the helper [105]. Transformants were selected using kanamycin $\left(100 \mu \mathrm{g} \mathrm{mL}^{-1}\right)$ and ampicillin $\left(100 \mu \mathrm{g} \mathrm{mL}^{-1}\right)$ resistance and green fluorescence.

\section{Colonization of sugarcane plantlets by GFP-tagged pPROBE-pTet ${ }^{r}-T T$ CY5 and CA1 bacteria}

Plantlets of micro-propagated cultivated sugarcane variety GT11 were obtained from Sugarcane Research Institute, Guangxi Academy of Agriculture Sciences, Nanning, China, and plantlets were inoculated with $\mathrm{Ba}$ cillus strains and GFP /pPROBEpTet ${ }^{\mathrm{r}}$-TT tagged Bacillus strains according to Oliveira et al. [105]. Five different plantlets were shifted in a glass container comprising $50 \mathrm{~mL}$ of liquid MS medium [106]. After twothree days, plantlets were shifted in bacterial suspension approximately $2.0 \times 10^{5} \mathrm{~mL}^{-1}$ cell count in autoclaved bottles and plantlets without bacterial suspension were used as a control, following the growth chamber condition of Li et al. [7].

\section{Confocal laser scanning microscopy}

After $96 \mathrm{~h}$ of bacterial inoculation, inoculated and uninoculated sugarcane plantlets were removed from the culture vessel and washed two to three times with autoclaved distilled water. The root, stem, and leaf were cut into small parts $(50$ to $150 \mu \mathrm{m})$ and then mounted them on the bridge slide with $10 \%(\mathrm{v} / \mathrm{v})$ glycerol. All plant sections were detected with a CLSM (Leica DMI 6000, Leica Microsystems, Mannheim, Germany).

\section{Evaluation of isolates in the greenhouse experiment}

The experiment was conducted in a greenhouse with two sugarcane verities GT11 and GXB9, at Guangxi University, Nanning, Guangxi, China. The plantlets of these varieties were provided by Sugarcane Research Institute, Guangxi Academy of Agricultural Sciences, Nanning, China. Forty healthy sugarcane plantlets of each sugarcane variety were divided into two groups i.e., 20-20. These selected plantlets were 30-40 days old, then washed with running tap water to remove all soil particles attached to the surface of the plants. All sugarcane plantlets were immersed in bacterial spore suspension set at $10^{6}$ spores $\mathrm{mL}^{-1}$ for $1 \mathrm{~h}$. After, these treatments, plantlets were transferred into plastic pots $(30 \mathrm{~cm}$ in diameter, $40 \mathrm{~cm}$ in-depth, two plants per pot) with $15 \mathrm{~kg}$ soil and sand mixture $(3: 1 \mathrm{w} / \mathrm{w})$. The plantlets without spore suspension treatment were used as the control for both varieties. After inoculation, the plantlets were grown in the pots under controlled conditions $(30 \pm$ $2{ }^{\circ} \mathrm{C},>80 \%$ relative humidity and $16 / 8 \mathrm{~h}$ light/dark cycle). Leaf, stem and root samples from both varieties were sampled at consecutive time intervals (30-120 days). Collected samples were immediately stored at $80^{\circ} \mathrm{C}$ until they were used for investigations.

\section{RNA extraction and CDNA synthesis}

RNA was extracted using Trizol reagent (Tiangen, China) and purified using a RNeasy Plant Mini Kit (Qiagen). The first-strand cDNA from DNase-treated RNA was synthesized using Prime-Script ${ }^{\mathrm{mi}}$ RT Reagent Kit (TaKaRa, China) according to the manufacturer's instructions.

\section{Real-time PCR quantification of $\mathrm{CY} 5$ and $\mathrm{CA} 1$}

The expression of nifH, CAT, PAL, SOD, CHI and GLU genes in leaf tissues of sugarcane during plantmicroorganism interaction was analyzed under a greenhouse condition after inoculation of selected strains (CY5 and CA1) in GT11 and GXB9 sugarcane varieties. Both sugarcane varieties were provided by Sugarcane Research Institute, Guangxi Academy of Agricultural 
Sciences, Nanning, China. The relative expression of all genes was measured by calculating the difference in the expression level of the inoculated sample and the control at 60 and 120 days with glyceraldehyde-3-phosphate dehydrogenase (GAPDH) as the reference gene.

Real-time quantitative PCR (RT-qPCR) was conducted with SYBR Premix Ex Tap ${ }^{\text {tm }}$ II (TaKaRa, Japan) and the reaction was completed in RT-PCR System (Bio-Rad, USA). The total reaction volume was $20 \mu \mathrm{L}$, the composition of the reaction mixtures and conditions were followed by Niu et al. [98]. The list of primers used is presented in Table 5. The specificity of the reaction was confirmed by melting curve analysis at the end of the amplification and $2^{-\triangle \Delta C t}$ method was used for quantification of relative gene expression [107]. Each RT-qPCR experiment was conducted in triplicate.

\section{Plant tissue analysis for ${ }^{15} \mathrm{~N}_{2}$ and $\% \mathrm{~N}$ by isotope dilution assay}

The nitrogen content of the dried plant tissues (root, leaf, and stem) was determined by the Institute of Genetics and Physiology, Hebei Academy of Agriculture and Forestry Sciences, China. Atom $\%{ }^{15} \mathrm{~N}_{2}$ was determined by $\mathrm{K} 05$ automatic Kjeldahl nitrogen determination apparatus (Shanghai Sonnen automated analysis instrument co. Ltd.), and elementary analysis isotope ratio mass spectrometers (Thermo Fisher DeltaV Advantage IRMS). The ${ }^{15} \mathrm{~N}_{2}$ isotope dilution assay was used to quantify the nitrogen fixed by CY5 and CA1, in the sugarcane varieties GT11 and GXB9. ${ }^{15} \mathrm{~N}_{2}$ isotope dilution assay of GT11 and GXB9 plants under the greenhouse condition was done as described by Lin et al. [108].

The method involves testing of an $\mathrm{N}_{2}$-fixing crop grown in a substrate with homogenous ${ }^{15} \mathrm{~N}_{2}$ enrichment ammonium sulfate ( $10 \mathrm{mg} \mathrm{kg}^{-1}$ of soil). Pots were filled with 15 $\mathrm{kg}$ of soil mixed with ${ }^{15} \mathrm{~N}_{2}$-labeled ammonium sulfate. Three plants of similar sizes and inoculated with CY5 and CA1 strains were transplanted in each pot. There were five replicates per treatment. Six months after planting, the plants were harvested and washed to remove the attached soil. Root, leaf, and stem were separated and dried at $65^{\circ} \mathrm{C}$ for $48 \mathrm{~h}$ and ground to make a fine powder, then sieved using a $0.5 \mathrm{~mm}$ mesh. The percentage of fixed $\mathrm{N}_{2}$ derived from the air (Ndfa) in the plant was determined according to the following equation [108].

$$
\begin{gathered}
\% \mathrm{Ndfa}=100 \times\left(1-\left(\text { atom } \%{ }^{15} \mathrm{~N}_{2} \text { excess from treatment }\right)\right. \\
\left./\left(\text { atom } \%{ }^{15} \mathrm{~N}_{2} \text { excess from control }\right)\right\}
\end{gathered}
$$

\section{Statistical data analysis}

The data were analyzed using analysis of variance (ANOVA) followed by Duncan's multiple range test
(DMRT). Standard errors were calculated for all mean values of three replicates and variations were measured significant at the $p \leq 0.05$ level by student's $t$-test. All plant growth-promoting rhizobacteria tests were conducted in triplicate, and the results were expressed as mean values. All the experiments including Biolog, microbial colonization, and RT-PCR were performed in duplicate and the results were assessed for consistency. OrigiPro 9.1 (2013) software was used for the principal component analysis (PCA).

\section{Supplementary information}

Supplementary information accompanies this paper at https://doi.org/10. 1186/s12870-020-02400-9. Additional files 1: Figure $\mathbf{S 1}$. acds gene amplification in nitrogen-fixing
bacteria and approximately $755 \mathrm{bp}$ fragments to be amplified. M is a mo-
lecular size marker (100 to $2000 \mathrm{bp}$ ), PC is positive control (Pseudomonas
entomophila), and NC is negative control (sterile water).

Additional files 2: Figure S2. PCR amplification with genomic DNA of nitrogen-fixing bacteria. The nifH gene fragment is amplified at $360 \mathrm{bp}$. M is a molecular size marker (100 to 2000 bp), Klebsiella verticola as a positive control (PC), and sterile water is negative control (NC).

Additional files 3: Figure S3. BOX fingerprinting of the screened bacterial isolates from sugarcane. Strain Codes: B1. CoY3, B2. CoY7, B3. CoY8, B4. CoA1, B5. CoA10, B6. AY6, B7. AY7, B8. AY8, B9. AN8, B10. AN11, B11. AN12, B12. BN5, B13. CY5, B14. CY9, B15. CY10, B16. CY11, B17. CA1, B18. CA6, B19. CA8, B20. CN13, B21. CN14 and B22. N1. M, molecular size marker from $100 \mathrm{bp}-5 \mathrm{~kb}$ (Takara). Figure S4. ERIC-PCR fingerprinting of selected bacteria from sugarcane. Strain Codes: B1. CoY3, B2. CoY7, B3. CoY8, B4. CoA1, B5. CoA10, B6. AY6, B7. AY7, B8. AY8, B9. AN8, B10. AN11, B11. AN12, B12. BN5, B13. CY5, B14. CY9, B15. CY10, B16. CY11, B17. CA1, B18. CA6, B19. CA8, B20. CN13, B21. CN14 and B22. N1. Without labelled gel lanes are not used in this study.

Additional files 4: Table S1. The number of substrates utilized by individual strains for Bacillus megaterium (CY5) and Bacillus mycoides (CA1).

Additional files 5: Table S2. Analysis of physical, chemical properties and trace elements structure in the soil of sugarcane plant.

Additional files 6: Table S3. The media used in this study for isolation of $\mathrm{N}_{2}$ fixing bacteria from sugarcane.

Additional files 7: Table S4. Composition and conditions of PCR amplification used for genetic fingerprinting analysis.

\footnotetext{
Abbreviations

ACC: 1-aminocyclopropane-1-carboxylate; ANOVA: Analysis of variance; ARA: Acetylene reduction assay; BLAST: Basic local alignment search tool; BOX: A1R-based repetitive extragenic palindromic; CAT: Catalase; $\mathrm{CHI}$ : Chitinase; DMRT: Duncan's multiple range test; EC: Electrical conductivity; ERIC: Enterobacterial repetitive intergenic consensus; GFP: Green fluorescent protein; GLU: Glucanase; HCN: Hydrogen cyanide; IAA: Indole acetic acid; MEGA: Molecular evolutionary genetics analysis; $\mathrm{N}$ : Nitrogen; $\left(\mathrm{NH}_{4}\right)_{2} \mathrm{SO}_{4}$ : Ammonium sulfate; $\mathrm{NCBI}$ : National center for biotechnology information; PGPR: Plant growth-promoting rhizobacteria; PAL: Phenylalanine ammonia-lyase; PCA: Principal component analysis; PCR: Polymerase chain reaction; qRT-PCR: Quantitative Real-Time polymerase chain reaction; SOD: Superoxide dismutase; UPGMA: Unweighted pair group method with arithmetic mean
}

Acknowledgements Not applicable. 


\section{Authors' contributions}

Conceptualization, RKS, PS, LY, and YL. Methodology, RKS, HL, PS. Software analysis, RKS. Validation, QS, and DG. Formal analysis, MKS, KKV, MKM. The investigation, LY, YL. Formal analysis, XS. Writing-original draft preparation, RKS, PS. Writing-review and editing, LY, YL, and PL. All authors read, edited and approved the final manuscript.

\section{Funding}

This research was funded by the National Natural Science Foundation of China (31471449, 31171504, 31101122), Guangxi Special Funds for Bagui Scholars and Distinguished Experts (2013-3), Guangxi Special Fund for Scientific Base and Talent (GKAD17195100). Fund for Guangxi Innovation Teams of Modern Agriculture Technology (GJNYTXGXCXTD-03-01) and Fund of Guangxi Academy of Agricultural Sciences (2015YT02 and GNKB2017028). The funding bodies were not involved in the design of the study, analysis, and interpretation of data in the manuscript.

\section{Availability of data and materials}

All data produced or evaluated through this study will be easily accessible with request to corresponding authors for reasonable request.

\section{Ethics approval and consent to participate}

This research article does not contain any ethical and consent approval.

\section{Consent for publication}

Not applicable.

\section{Competing interests}

The authors declare that they have no competing interests.

\section{Author details}

'Key Laboratory of Sugarcane Biotechnology and Genetic Improvement (Guangxi), Ministry of Agriculture, Sugarcane Research Center, Chinese Academy of Agricultural Sciences, Guangxi Key Laboratory of Sugarcane Genetic Improvement, Sugarcane Research Institute, Guangxi Academy of Agricultural Sciences, Nanning 530007, Guangxi, China. ${ }^{2}$ College of Agriculture, State Key Laboratory of Conservation and Utilization of Subtropical Agro-bio resources, Guangxi University, Nanning 530005, China. ${ }^{3}$ Guangxi Key Laboratory of Crop Genetic Improvement and Biotechnology, Nanning 530007, Guangxi, China. ${ }^{4}$ Department of Food Quality and Safety, Institute for Post-harvest and Food Sciences, The Volcani Center, Agricultural Research Organization, 7528809 Rishon LeZion, Israel. ${ }^{5}$ Queensland Alliance for Agriculture and Food Innovation, The University of Queensland, St Lucia, QLD 4072, Australia.

\section{Received: 30 August 2019 Accepted: 21 April 2020} Published online: 18 May 2020

\section{References}

1. Dwight T, Lakshmanan P, Songstad DD. "Biofuels" Global impact on renewable energy, production agriculture and technological advancement, Springer, USA; 2011 . p. 357.

2. FAO. Top Sugarcane Production: Food and Agriculture Organization of the United Nations. Rome: FAO; 2018.

3. Singh RK, Singh P, Li HB, Yang LT, Li YR. "Soil-Plant-Microbe Interactions" Use of nitrogen-fixing bacteria for plant growth and development in sugarcane. In: Singh DP, et al., editors. "Plant-Microbe Interactions in AgroEcological Perspectives". Singapore Pte Ltd. Springer Nature; 2017. https:// doi.org/10.1007/978-981-10-5813-4-3.

4. Robinson N, Brackin R, Vinall K, Soper F, Holst J, Gamage H, PaungfooLonhienne C, Rennenberg H, Lakshmanan P, Schmidt S. Nitrate paradigm does not hold up for sugarcane. PLoS One. 2011;6(4):e19045.

5. Li RY, Yang LT. Sugarcane agriculture and sugar industry in China. Sugar Tech. 2015:17:1-8.

6. Lal R. Climate change and soil degradation mitigation by sustainable management of soils and other natural resources. Agric Res. 2012;1(3):199212.

7. Li HB, Singh RK, Singh P, Song QQ, Xing YX, Yang LT, Li YR. Genetic diversity of nitrogen-fixing and plant growth promoting Pseudomonas species isolated from sugarcane rhizosphere. Front Microbiol. 2017. https://doi.org/ 10.3389/fmicb.2017.01268.
8. Glick BR. Plant growth-promoting bacteria, mechanisms and applications. Scientifica (Cairo). 2012;963401. https://doi.org/10.6064/2012/963401.

9. Paungfoo-Lonhienne C, Lonhienne TGA, Yeoh YK, Webb Rl, Lakshmanan P, Chan CX, Lim PE, Ragan MA, Schmidt S, Hugenholtz P. A new species of Burkholderia isolated from sugarcane roots promotes plant growth. Microb Biotechnol. 2014;7(2):142-54.

10. Sahoo RK, Ansari MW, Dangar TK, Mohanty S, Tuteja N. Phenotypic and molecular characterisation of efficient nitrogen-fixing Azotobacter strains from rice fields for crop improvement. Protoplasma. 2014;251:511-23.

11. Venieraki A, Dimou M, Pergalis P, Kefalogianni I, Chatzipavlidis I, Katinakis P. The genetic diversity of culturable nitrogen-fixing bacteria in the rhizosphere of wheat. Microb Eco. 2011;61:277-85.

12. Boddey RM, de Oliveira OC, Urquiaga S, Reis VM, Olivares FL, Baldani VLD, DoĖbereiner J. Biological nitrogen fixation associated with sugar cane and rice: contributions and prospects for improvement. Plant Soil. 1995;174:195209.

13. Silveira APD, Sala VMR, Cardoso EJBN, Labanca EG, Cipriano MAP. Nitrogen metabolism and growth of wheat plant under diazotrophic endophytic bacteria inoculation. Appl Soil Ecol. 2016;107:313-9.

14. Liu X, Zhao H, Chen S. Coloniation of maize and rice plants by strain Bacillus megaterium C4. Cur Microbiol. 2006:52:186-90.

15. Munusamy M, Selvaraj P, Lee J-S, Lee K-C, Kuppusamy H. Bacillus rhizosphaerae sp. nov., an novel diazotrophic bacterium isolated from sugarcane rhizosphere soil. Antonie van Leeuwenhoek. 2011;100:437-44.

16. Reis VM, P., los Santos E-d, Tenorio-Salgado S, Vogel J, Stoffels M, Guyon S, Mavingui P, Baldani VLD, Schmid M, Baldani JL, Balandreau J, Hartmann A, CaballeroMellado J. Burkholderia tropica sp. nov., a novel nitrogen fixing, plant-associated bacterium. Int J Syst Evol Microbiol. 2004;54:2155-62.

17. Goris J, De Vos P, Caballero-Mellado J, Park J, Falsen E, Quensen JF, Tiedje $J M$, Vandamme P. Classification of the PCB- and biphenyl-degrading strain LB400 and relatives as Burkholderia xenovorans sp. nov. Int J Syst Evol Microbiol. 2004:54:1677-81.

18. Perin L, Martinez-Aguilar L, Paredes-Valdez G, Baldani J, Estrada-de los Santos P, Reis VM, Caballero-Mellado J. Burkholderia silvatlantica sp. nov., a diazotrophic bacterium associated with sugarcane and maize. Int J Syst Evol Microbiol. 2006:56:1931-7.

19. Martínez-Aguilar L, Salazar-Salazar C, Méndez RD, Caballero-Mellado J, Hirsch AM, Vásquez-Murrieta MS, Estrada-de los Santos P. Burkholderia caballeronis sp. nov., a nitrogen fixing species isolated from tomato (Lycopersicon esculentum) with the ability to effectively nodulate Phaseolus vulgaris. Antonie Van Leeuwenhoek. 2013;104(6):1063-71.

20. Salvagiotti F, Cassman KG, Specht JE, Walters DT, Weiss A, Doberman A. Nitrogen uptake, fixation, and response to fertilizer $\mathrm{N}$ in soybeans: a review. Field Crops Res. 2008;108:1-13.

21. Han J, Sun L, Dong X, Cai Z, Sun X, Yang H, Wang Y, Song W. Characterization of a novel plant growth-promoting bacteria strain Delftia tsuruhatensis HR4 both as a diazotroph and a potential biocontrol agent against various plant pathogens. Syst Appl Microbiol. 2005;28(1):66-76.

22. Zhu B, Qing Z, Lin L, Hu C, Shen P, Yang L, Qianli A, Guanlin X, Yangrui L. Enterobacter sacchari sp. nov., a nitrogen-fixing bacterium associated with sugarcane (Saccharum officinarum L.). Int J Syst Evol Microbiol. 2013;63: 2577-82.

23. Boddey RM, Urquiaga $S$, Alves Burno JR, Reis $V$. Endophytic nitrogen fixation in sugarcane: present knowledge and future applications. Plant Soil. 2003; 252:139-49.

24. Vargas L, Santa-Brígida AB, Mota-Filho JP, de Carvalho TG, Rojas CA, Vaneechoutte D, Van Bel M, Farrinelli L, Ferreira PCG, Vandepoele K, Hemerly AS. Drought tolerance conferred to sugarcane by association with Gluconacetobacter diazotrophicus: a transcriptomic view of hormone pathways. PLoS One. 2014;9:e114744.

25. Yong-Xiu X, Chun-Yan W, Yao M, Yang L-T, Si-Liang H, Yang-Rui L. Nitrogenfixing and plant growth-promoting ability of two endophytic bacterial strains isolated from sugarcane stalks. Sugar Tech. 2015;18(4):373-9.

26. Ehrmann J, Ritz K. Plant: soil interactions in temperate multi-cropping production systems. Plant Soil. 2014;376:1-29.

27. Hong Y, Ma Y, Wu L, Maki M, Qin W, Chen S. Characterization and analysis of nifH genes from Paenibacillus sabinae T27. Microbiol Res. 2012;167:59660.

28. Ankit K, Anil P, Johri BN. Bacillus as PGPR in crop ecosystem. In: Maheshwari DK, editor. Bacteria in Agrobiology: crop ecosystems, Springer-Verlag Berlin Heidelberg; 2011. p. 37-59. 
29. Singh RK, Kumar DP, Solanki MK, Singh P, Srivastava S, Srivastva AK, Kumar S, Kashayp PL, Singhal PK, Arora DK. Multifarious plant growth promoting characteristics of chickpea rhizosphere associated bacilli help to suppress soil-borne pathogens. Plant Growth Regul. 2013;73:91-101.

30. Solanki MK, Wang Z, Wang FY, Li CN, Lan TJ, Singh RK, Singh P, Yang LT, Yang RL. Intercropping in sugarcane cultivation influenced the soil properties and enhanced the diversity of vital diazotrophic bacteria. Sugar Tech. 2016. https://doi.org/10.1007/s12355-016-0445-y.

31. Velazquez E, Rojas M, Lorite MJ, Rivas R, Zurdo-Pineiro JL, Heydrich M, Bedmar EJ. Genetic diversity of endophytic bacteria which could be find in the apoplastic sap of the medullary parenchyma of the stem of healthy sugarcane plants. J Basic Microbiol. 2008;48:118-24.

32. Kruasuwan W, Thamchaipenet A. Diversity of culturable plant growthpromoting bacterial endophytes associated with sugarcane roots and their effect of growth by co-inoculation of diazotrophs and actinomycetes. J Plant Growth Regul. 2016;35(4):1074-87.

33. Dobereiner J. Nitrogen fixing bacteria of the genus Beijerinckia Drex. In the rhizosphere of sugarcane. Plant Soil. 1961;15:211-6.

34. Costa PBD, Granada CE, Ambrosini A, Moreira F, de Souza R, dos Passos JFM, Arruda L, Passaglia LMP. A model to explain plant growth promotion traits: a multivariate analysis of 2211 bacterial isolates. PLoS One. 2014;9:e116020.

35. Govindasamy V, Senthilkumar M, Magheshwaran V, Kumar U, Bose P, Sharma V, Annapurna K. Bacillus and Paenibacillus spp.: potential PGPR for sustainable agriculture. In: Maheshwari DK, editor. Plant growth and health promoting Bacteria. Berlin Heidelberg: Springer; 2011. p. 333-64.

36. Parke JL, Gurian-Sherman D. Diversity of the Burkholderia cepacia complex and implications for risk assessment of biological control strains. Annu Rev Phytopathol. 2001;39:225-58.

37. Suárez-Moreno Z, Caballero-Mellado J, Coutinho B, Mendonça-Previato L, James E, Venturi V. Common features of environmental and potentially beneficial plant-associated Burkholderia. Microb Ecol. 2012;63:249-66.

38. Dobereiner J, Ruschel AP. A new species of Beijerinckia (in Portuguese, with abstract in English). Rev Biol. 1958;1:261-72.

39. Dobereiner J. Biological nitrogen fixation in the tropics, social and economic contributions. Soil Biol Biochem. 1997;29:771-4.

40. Baldani Jl, Reis VM, Baldani VLD, Dobereiner J. A brief story of nitrogen fixation in sugarcane reasons for success in Brazil. Funct Plant Biol. 2002;29: 417-23.

41. Xie GH, Su BL, Cui ZJ. Isolation and identification of $\mathrm{N}_{2}$-fixing strains of Bacillus in rice rhizosphere of the Yangtze River valley. Acta Microbiol Sin. 1998:38:480-3.

42. Elo S, Suominen I, Kampfer P, Juhanoja J, Salkinoja-Salonen M, Haahtela K. Paenibacillus borealis sp. nov.; a nitrogen fixing species isolated from spruce forest humus in Finland. Int J Syst Evol Microbiol. 2001;51:535-45.

43. Berge $\mathrm{O}$, Guinebretiere MH, Achouak W, Normand P, Heulin T. Paenibacillus graminis sp. nov. and Paenibacillus odorifer sp. nov.; isolated from plant roots, soil and food. Int J Syst Evol Microbiol. 2002;52:607-16.

44. Von der Weid I, Duarte GF, van Elsas JD. Paenibacillus brasilensis sp. nov.; a novel nitrogen-fixing species isolated from the maize rhizosphere in Brazil. Int J Syst Evol Microbiol. 2002;52:2147-53.

45. Achouak W, Normand P, Heulin T. Comparative phylogeny of rrs and nifH genes in the Bacillaceae. Int J Syst Bacteriol. 1999;49:961-7.

46. Lugtenberg BJJ, Dekkers L, Bloemberg GV. Molecular determinants of rhizosphere colonization by Pseudomonas. Annu Rev Phytopathol. 2001;39: 461-90.

47. Compant S, Clement C, Sessitsch A. Plant growth-promoting bacteria in the rhizo- and endosphere of plants, their role, colonization, mechanisms involved and prospects for utilization. Soil Biol Biochem. 2010;42:669-78.

48. Ambrosini A, Sant'Anna FH, de Souza R, Tadra-Sfeir M, Faoro H, Alvarenga SM, Pedrosa FO, Souza EM, Passaglia LMP. Genome sequence of Bacillus mycoides B38V, a growth-promoting bacterium of sunflower. Genome Announc. 2015:3:e00245-15.

49. Ogut M. Fatih Er, Kandemir N. phosphate solubilisation potential of soil Acinetobacter strains. Biol Fertil Soils. 2010;46:707-15.

50. Dobbelaere S, Vanderleyden J, YaacovOkon Y. Plant growth-promoting effects of diazotrophs in the rhizosphere. Crit Rev Plant Sci. 2003;22:147-9.

51. Rifat H, Safdar A, Ummay A, Rabia K, Iftikhar A. Soil beneficial bacteria and their role in plant growth promotion, a review. Ann Microbiol. 2010;60:579-98.

52. Pikovskaya RI. Mobilization of phosphorus in soil in connection with the vital activity of some of the microbial species. Microbiologiya. 1948;17: $362-70$.
53. Radzki W, Gutierrez MFJ, Algar E, Lucas GJA, Garcia VA, Ramos SB. Bacterial siderophores efficiently provide iron to iron-starved tomato plants in hydroponics culture. Anton V Leeuwen. 2013;104:321-30.

54. Jaber M, Harald K, Omer E, Konrad M. The central role of microbial activity for iron acquisition in maize and sunflower. Biol Fertil Soil. 2002;30:433-9.

55. Que $Y X, X u L P$, Lin JW, Chen RK, Grisham MP. Molecular variation of Sporisorium scitamineum in mainland China revealed by RAPD and SRAP markers. Plant Dis. 2012;96:1519-25..

56. Marques APGC, Pires C, Moreira H, Rangel AOSS, Castro PML. Assessment of the plant growth promotion abilities of six bacterial isolates using Zea mays as indicator plant. Soil Biol Biochem. 2010;42:1229-35.

57. Belimov AA, Safronova VI, Mimura T. Response of spring rape (Brassica napus L. var. Oleifera) to inoculation with plant growth promoting rhizobacteria containing 1-aminocyclopropane-1-carboxylate deaminase depends on nutrient status of the plant. Can J Microbiol. 2002;48:189-99.

58. Glick BR, Penrose DM, Li J. A model for the lowering of plant ethylene concentration by plant growth-promoting bacteria. J Theor Biol. 1998;190:63-8.

59. Nascimento FX, Rossi MJ, Soares CRFS, McConkey BJ, Glick BR. New insights into 1-Aminocyclopropane-1-carboxylate (ACC) Deaminase phylogeny, Evolution and Ecological Significance. PLoS ONE. 2014;9(6):e99168.

60. Blaha D, Prigent-Combaret C, Mirza MS, MoenneLoccoz Y. Phylogeny of the 1-aminocyclopropane-1-carboxylic acid deaminase encoding gene acdS in phytobeneficial and pathogenic Proteobacteria and relation with strain biogeography. FEMS Microbiol Ecol. 2006;56:455-70.

61. Onofre-Lemus J, Hernandez-Lucas I, Girard L, Caballero-Mellado J. ACC (1aminocyclopropane-1- carboxylate) deaminase activity, a widespread trait in Burkholderia species, and its growth-promoting effect on tomato plants. Appl Environ Microbiol. 2009;75:6581-90.

62. Idris SE, Iglesias DJ, Talon M, Borriss R. Tryptophan-dependent production of indole-3-acetic acid (IAA) affects level of plant growth promotion by Bacillus amyloliquefaciens FZB42. Mol Plant-Microbe Interact. 2007;20:619-26.

63. Zehr JP, Capone DG. Problems and promises of assaying the genetic potential for nitrogen fixation in the marine environment. Microb Ecol. 1996:32:263-81.

64. Zehr JP, Jenkins BD, Short SM, Steward GF. Nitrogenase gene diversity and microbial community structure, a cross-system comparison. Environ Microbiol. 2003;5:539-54.

65. Versalovic J, Koeuth T, Lupski JR. Distribution of repetitive DNA sequences in eubacteria and application to fingerprinting of bacterial genomes. Nucleic Acids Res. 1991;19:6823-31.

66. Wielbo J, Marek-Kozaczuk M, Kubik-Komar A, Skorupska A. Increased metabolic potential of Rhizobium spp. is associated with bacterial competitiveness. Can J Microbiol. 2007;53:957-67.

67. Mazur A, Stasiak G, Wielbo J, Koper P, Kubik-Komar A, Skorupska A. Phenotype profiling of Rhizobium leguminosarum bv. Trifolii clover nodule isolates reveal their both versatile and specialized metabolic capabilities. Arch Microbiol. 2013;195:255-67.

68. Lin L, Guo W, Xing Y, Zhang X, Li Z, Hu C, Song L, Li YR, An Q. The actinobacterium Microbacterium sp. 16SH accepts pBBR1-based pPROBE vectors, forms biofilms, invades roots, and fixes N2 associated with micropropagated sugarcane plants. Appl Microbiol Biotechnol. 2012;93:1185-95.

69. Noda S, Ohkuma M, Usami R, Horikoshi K, Kudo T. Culture-independent characterization of a gene responsible for nitrogen fixation in the symbiotic microbial community in the gut of the termite Neotermes koshunensis. Appl Environ Microbiol. 1999;65:4935-42.

70. Singh P, Song QQ, Singh RK, Li HB, Solanki MK, Malviya MK, Verma KK, Yang LT, Li YR. Proteomic analysis of the resistance mechanisms in sugarcane during Sporisorium scitamineum infection. Int J Mol Sci. 2019;20:569. https:// doi.org/10.3390/ijms20030569.

71. Su Y, Guo J, Ling H, Chen S, Wang S, Xu L, Allan AC, Que Y. Isolation of a novel peroxisomal catalase gene from sugarcane, which is responsive to biotic and abiotic stresses. PLoS One. 2014;9(1):e84426.

72. Chen HJ, Wu SD, Huang GJ, Shen CY, Afiyanti M, Li WJ, Lin YH. Expression of a cloned sweet potato catalase SPCAT1 alleviates ethephon-mediated leaf senescence and H2O2 elevation. J Plant Physiol. 2012;169:86-97.

73. Williamson JD, Scandalios JG. Differential response of maize catalases and superoxide dismutases to the photoactivated fungal toxin cercosporin. The Plant J. 1992;2:351-8.

74. Song XP, Huang X, Mo FL, Tian DD, Yang LT, Li YR, Chen BS. Cloning and expression analysis of sugarcane phenylalanin ammonia-lyase (PAL) gene. Sci Agric Sin. 2013;46:2856-68. 
75. Jain R, Chandra A, Venugopalan VK, Solomon S. Physiological changes and expression of SOD and P5CS genes in response to water deficit in sugarcane. Sugar Tech. 2015;17:276-82.

76. Leubner-Metzger G. Functions and regulation of plant b-1,3-glucanases (PR2). J Cyst Fibros. 2012;11:49-76.

77. Libantová J, Kämäräinen T, Moravčíková J, Matušíková I, Salaj J. Detection of chitinolytic enzymes with different substrate specificity in tissues of intact sundew (Drosera rotundifolia L.). Mol Biol Rep. 2009;36:851-6.

78. Singh P, Song QQ, Singh RK, Li HB, Solanki MK, Yang LT, Li YR. Physiological and molecular analysis of sugarcane (varieties- F134 and NCO310) during Sporisorium scitamineum interaction. Sugar Tech. 2018. https://doi.org/10. 1007/s12355-018-0671-6.

79. Porat R, Vinokur V, Holland D, Gregory McCollum T, Droby S. Isolation of a citrus chitinase CDNA and characterization of its expression in response to elicitation of fruit pathogen resistance. J Plant Physiol. 2001;158:1585-90.

80. Wan LL, Zha WJ, Cheng XY, Liu C, Lv L, Liu CX, Wang Z, Du B, Chen R, Zhu $\mathrm{L}$, He G. A rice b-1, 3-glucanasegene Osg1 is required for callose degradation in pollen development. Planta. 2011;233:309-23.

81. Tao $Y$, Xie B, Yang $Z$, Chen $Z$, Chen $B$, Deng $Y$, Jiang $Y$, van Peer AF. Identification and expression analysis of a new glycoside hydrolase family 55 exo-b-1, 3-glucanase-encoding gene in Volvariella volvacea suggests a role in fruiting body development. Gene. 2013;527:154-60.

82. Urquiaga S, Cruz K, Boddey R. Contribution of nitrogen fixation to sugarcane, nitrogen-15 and nitrogen balance estimates. Soil Sci Soc Am J. 1992;56:105-14.

83. Baldani VLD, Baldani Jl, Olivares FL, Döbereiner J. Identification and ecology of Herbaspirillum seopedicae and the closely related Pseudomonas rubrisubalbicans. Symbiosis. 1992;19:65-73.

84. Baldani Jl. Ocorrência e caracterização de Azospirillum amazonense em comparação com outras espécies deste gênero, em raízes de milho, sorgo e arroz. Federal Rural University of Rio de Janeiro, Seropédica, 1984; MSc Thesis.

85. Singh RK, Kumar DP, Solanki MK, Singh P, Srivastava S, Srivastva AK, Kumar S, Kashayp PL, Saxena AK, Singhal PK, Arora DK. Optimization of media components for chitinase production by chickpea rhizosphere associated Lysinibacillus fusiformis B-CM18. J Basic Microbiol. 2012;52:1-10.

86. Schwyn B, Neilands JB. Universal chemical assay for the detection and determination of siderophores. Anal Biochem. 1987;160:47-56.

87. Lorck H. Production of hydrocyanic acid by bacteria. Physiol Plant. 1948;1: 142-6.

88. Dey R, Pal KK, Bhatt DM, Chauhan SM. Growth promotion and yield enhancement of peanut (Arachis hypogaea $\mathrm{L}$ ) by application of plant growth promoting rhizobacteria. Microbiol Res. 2004;159:371-94.

89. Glickmann E, Dessaux Y. A critical examination of the specificity of the Salkowski reagent for indolic compounds produced by phytopathogenic bacteria. Appl Environ Microbiol. 1995;61:793-6.

90. Jacobson CB, Pasternak JJ, Glick BR. Partial purification and characterization of 1-aminocyclopropane-1-carboxylate deaminase from the plant growth promoting rhizobacterium Pseudomonas putida GR12-2. Can J Microbiol. 1994;40:1019-25.

91. Zhengyi L, Siping C, Shuting Y, Mingyue C, Lin L, Yuanyuan L, Shuying L, Qianli A. Differentiation of 1-aminocyclopropane-1-carboxylate (ACC) deaminase from its homologs is the key for identifying bacteria containing ACC deaminase. FEMS Microbiol Ecol. 2015;91:fiv112. https://doi.org/10. 1093/femsec/fiv112.

92. Honma M, Shimomura T. Metabolism of 1-aminocyclopropane-1- carboxylic acid. Agric Biol Chem. 1978;42:1825-31.

93. Hardy RF, Holsten RD, Jackson EK, Burn R. The acetylene-ethylene assay for $\mathrm{N}_{2}$ fixation, laboratory and field evaluation. Plant Physiol. 1968;43:1185-207.

94. Ki JS, Zhang W, Qian PY. Discovery of marine Bacillus species by $16 \mathrm{~S}$ rRNA and rpoB comparisons and their usefulness for species identification. J Microbiol Methods. 2009;77:48-57.

95. Edwards U, Rogall TH, Blocker H, Emde M, Bottger EC. Isolation and direct complete nucleotide determination of entire genes. Characterization of a gene coding for 165 ribosomal RNA. Nucleic Acids Res. 1989;17:7843-53.

96. Versalovic J, Schneider M, de-Bruijn FJ, Lupski JR. Genomic fingerprinting of Bacteria using repetitive sequence-based polymerase chain reaction. Methods Mol Cell Biol. 1994;5:25-40.

97. Poly F, Monrozier LJ, Bally R. Improvement in the RFLP procedure for studying the diversity of nifH genes in communities of nitrogen fixers in soil. Res Microbiol. 2001;152:95-103.
98. Niu JQ, Wang AQ, Huang JL, Yang LT, Li YR. Isolation, characterization and promoter analysis of cell wall invertase gene SOCIN1 from sugarcane (Saccharum spp.). Sugar Tech. 2015;17:65-76.

99. Su YC, Xu LP, Xue BT, Wu QB, Guo JL, Wu LG, Que YX. Molecular cloning 840 and characterization of two pathogenesis related B-1,3-glucanase genes ScGluA1 and ScGluD1841 from sugarcane infected by Sporisorium scitamineum. Plant Cell Rep. 2013;32:1503-19.

100. Saitou N, Nei M. The neighbor-joining method, a new method for reconstructing phylogenetic trees. Mol Biol Evol. 1987;4:406-25.

101. Kumar S, Stecher G, Tamura K. MEGA7, molecular evolutionary genetics analysis version 7.0 for bigger datasets. Mol Bio Evol. 2016;33:1870-4.

102. PHA S, Sokal RR. Numerical Taxonomy. The principles and practice of numerical classification. San Francisco: Freeman; 1973. p. 573.

103. Felsenstein J. Confidence limits on phylogenies, an approach using the bootstrap. Evolution. 1985;39:783-91.

104. Bochner BR. Global phenotypic characterization of bacteria. FEMS Microbiol Rev. 2009;33:191-205.

105. Oliveira ALM, Urquiaga S, Dobereiner J, Baldani Jl. The effect of inoculating endophytic $\mathrm{N}_{2}$-fixing bacteria on micropropagated sugarcane plants. Plant Soil. 2002;242:205-15.

106. Reis VM, Olivares FL, de Oliveira ALM, dos Reis Jr FB, Baldani Jl, Dobereiner J. Technical approaches to inoculate micro-propagated sugarcane plants with Acetobacter diazotrophicus. Plant Soil. 1999;206:205-11.

107. Livak KJ, Schmittgen TD. Analysis of relative gene expression data using real-time quantitative PCR and the $2^{-\Delta \Delta C t}$ method. Methods. 2001;25:402-8.

108. Lin L, Li Z, Hu C, Zhang X, Chang S, Yang LT, Yang RL, An Q. Plant growthpromoting nitrogen-fixing enterobacteria are in association with sugarcane plants growing in Guangxi, China. Microbes Environ. 2012b;4:391-8..

\section{Publisher's Note}

Springer Nature remains neutral with regard to jurisdictional claims in published maps and institutional affiliations.

Ready to submit your research? Choose BMC and benefit from

- fast, convenient online submission

- thorough peer review by experienced researchers in your field

- rapid publication on acceptance

- support for research data, including large and complex data types

- gold Open Access which fosters wider collaboration and increased citations

- maximum visibility for your research: over $100 \mathrm{M}$ website views per year

At BMC, research is always in progress.

Learn more biomedcentral.com/submissions 